\title{
LINEAR BAND POTTERY CULTURE (LBK) LITHIC INDUSTRY FROM APC
}

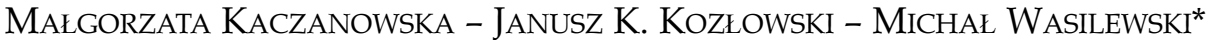

The general inventory of the chipped stone artefacts coming from the LBK features at Apc indicates that a specific, small scale, local lithic production was conducted on-site. Majority of used raw materials are limnoquartzites (nearly 70\%) originating mainly from the Mátra and Cserhát Mountains. The use of rather poor quality local raw materials influenced the technique of working raw materials, which was employed throughout the period of the functioning of LBK settlements at Apc. As a consequence, most tools were made on flakes. At the same time, as early as the oldest phase a limited supply of blade blanks and blade tools, produced elsewhere, was used. The ground stone artefacts and fragments included lower and upper grinding stones, plaquettes with polished surfaces, hammerstones, grinders/pounders. The raw materials used in the ground stone industry are either local (quartz, conglomerate, sandstone) or mesolocal (gabbro, basalt) coming from river alluvia or from the hills at the Hungarian-Slovakian border. Andesites, probably from the Mátra Mountains, occur in small quantities. Thus, the raw materials exploited at Apc demonstrate contacts with eastern region, however the site is the easternmost LBK settlement.

Keywords: Western Linear Band Pottery Culture (LBK), pre-Notenkopf phase, Notenkopf phase, Želiezovce Phase, raw material sources, limnoquartzites, quartz, conglomerate, sandstones

Az apci lelöhely VK-objektumaiból származó pattintottkö-leletek általános összetétele arra vall, hogy a telepen speciális, kis léptékü, helyi köeszköz-elöállitás folyt. Legnagyobb mennyiségben (közel 70\%) limnokvarcitokat használtak fel nyersanyagként, amelyek a Mátra és a Cserhát hegységböl származtak. A többnyire gyenge minőségü nyersanyagok felhasználása befolyásolta a feldolgozási technikákat is, amelyek nem változtak az apci VK-telep teljes fennállása alatt. Ennek következtében az eszközök nagyrészt szilánkon készülttek. Ugyanakkor már a telep életének legkorábbi fázisától kezdve használtak egy kevés pengét és pengeeszközt is, amelyeket máshonnan szereztek be. A csiszolt eszközök és szerszámkövek között találunk alsó és felső ôrlőköveket, csiszolt felületü kőlapokat, ütököveket és mozsártöröket, valamint azok töredékeit. Az ebben az iparban felhasznált nyersanyagok vagy helyiek (kvarc, konglomerátum, homokkő), vagy regionálisak (gabbró, bazalt), amelyek folyóüledékekböl vagy a magyar-szlovák határnál lévö hegyekböl származhatnak. Kis mennyiségben elöfordul andezit is, valószinüleg a Mátrából. Így hát az Apcon felhasznált kőnyersanyagok keleti területekkel mutatnak kapcsolatot, holott a lelóhely a nyugati VK legkeletibb települése.

Kulcsszavak: nyugati vonaldíszes kerámia kultúrája (VK), pre-kottafejes fázis, kottafejes fázis, zselízi fázis, nyersanyagforrások, limnokvarcitok, kvarc, konglomerátum, homokkövek

A kézirat érkezett: 2016. február 5.

* Małgorzata Kaczanowska. Polish Academy of Arts and Sciences, PL-31016 Kraków, ul. Sławkowska 17; malgorzatakacz@wp.pl. Janusz K. Kozłowski. Institute of Archaeology,
Jagiellonian University, PL-31007 Kraków, ul. Gołębia 11; janusz.kozlowski@uj.edu.pl. Michał Wasilewski. Institute of Archaeology, Jagiellonian University, PL-31007 Kraków, ul. Gołębia 11; mikewas.pl@gmail.com 
The site of Apc-Berekalja I is situated at the eastern periphery of the LBK. Excavations in 20082009 confirmed the multiphase evolution of the site from pre-Notenkopf to Želiezovce phases. ${ }^{1}$ In consequence, we have an opportunity to study in Apc the local evolution of the LBK lithic industry.

\section{Chipped stone artefacts}

The LBK features at Apc provided 408 chipped stones. The structure of the main technological groups is presented in the table below. In comparison with other LBK sites in northwestern Hungary and southwestern Slovakia, the series of lithic artefacts seems large. However, in proportion to the excavated area and considering the fact that all the phases of the LBK are represented, the number of artefacts is small. ${ }^{2}$

Table 1. Main technological categories in LBK features in Apc

1. táblázat. Az apci VK-objektumok fó technológiai csoportjai

\begin{tabular}{|l|r|r|}
\hline \multicolumn{1}{|c|}{ Technological category } & $\mathrm{N}$ & $\%$ \\
\hline Cores & 43 & 10.54 \\
\hline Flakes & 206 & 50.49 \\
\hline Blades & 27 & 6.62 \\
\hline Tools & 42 & 10.29 \\
\hline Splintered pieces & 12 & 2.94 \\
\hline Fragments & 19 & 4.66 \\
\hline Chips & 51 & 12.50 \\
\hline $\begin{array}{l}\text { Chunks, others (1 hammer- } \\
\text { stone, } 1 \text { gunflint) }\end{array}$ & 8 & 1.96 \\
\hline TOTAL & 408 & 100.00 \\
\hline
\end{tabular}

The general inventory structure indicates that a specific, small scale, local lithic production was conducted on-site. The role of blades was minor, while flakes were more important. The majority of tools were made on flakes. The proportion of cores is fairly large which was, probably, caused by the poor quality and poor cleavage of raw materials.

\section{Raw materials used for chipped stone industry}

The majority of used raw materials are siliceous rocks, mainly limnoquartzites (nearly $70 \%$ ). The most frequent types are known in the southern

1 DOMBORÓCZKI et al. in this volume.

2 KACZANOWSKA 2003; KACZANOWSKA-KOZŁOWSKI 2003. and southwestern part of the Mátra Mountains and in the Cserhát Mountains, about $20 \mathrm{~km}$ from the site. Some limnoquartzites may originate from the region west of Gyöngyös and from the Avas Hill in Miskolc (about 70-80 km to the east of the site). The only extralocal raw material was obsidian, but its proportion is only $1.7 \%$. Moreover, in pit 762 at a depth of $20-40 \mathrm{~cm}$ an end-scraper from Cretaceous flint from Upper Dniester basin was recovered, which is probably a younger intrusion.

\section{Ground stone industry}

The collection of ground stone artefacts contains almost 160 items. They were described and identified only on the basis of macroscopic petrographical examination. The method and tools used for raw material identification were simple; however the fieldwork in the area of Eger and some Mátra outcrops as well as careful reference to papers on ground stone industry in Northern Hungary gave a basis for more elaborate and precise assertions and conclusions. ${ }^{3}$ The results of the research are summarized in Fig. 1.

\section{Raw materials used for ground stone industry}

The site of Apc is situated on the western border of the Mátra Mountains, about $50 \mathrm{~km}$ westsouthwest of Eger. Geographically, this is a part of the Western Carpathians forming its southwestern edge. ${ }^{4}$ From a geological point of view, the area is a part of the Bükk Belt, ${ }^{5}$ which is com-

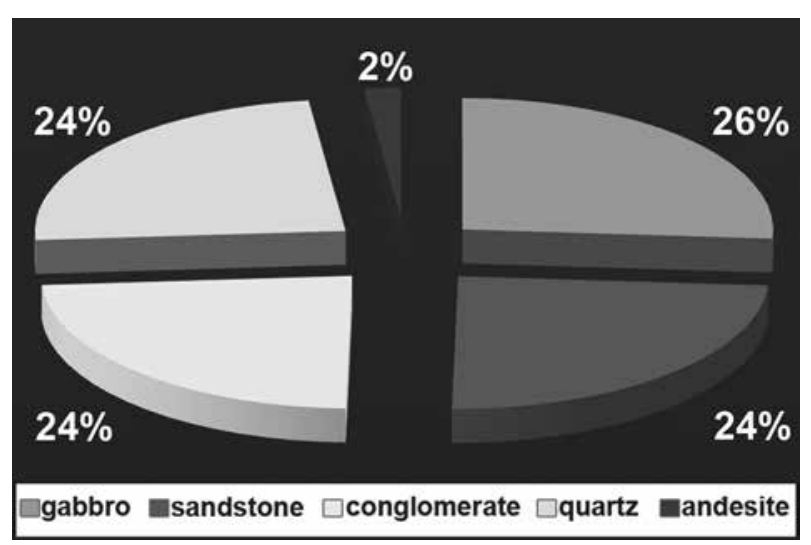

Fig. 1. Raw materials used for ground and polished stones 1. kép. Őrlőkövek és csiszolt kőeszközök nyersanyagai

\footnotetext{
3 E.g. Starnini-SZAKMÁNy 1994, 1998; SzAKMÁNY 1996; SZAKMÁNY-STARNINI 2002.

4 GERCSÁK 2002.

5 FÖldVARY 1988; PlašIENKA et al. 1997; HóK et al. 2001.
} 
posed mostly of Mesozoic rocks (carbonate and magmatic) interspersed with numerous younger (neovolcanic i.e. Cenozoic; 30-15 Ma) magmatic and volcanic formations. There are also other, younger rocks (e.g. clays, sands, tuffs).

These nappe, sedimentary and volcanic complexes are characterized by quite complicated tectonics and alternating stratigraphy, which causes surface accessibility of numerous rock types. ${ }^{6}$ The rift character of the volcanism in the Bükk Belt caused the fairly alkaline (gabbro-basalt) composition of rocks in the Bükk Mountains and alkaline-neutral (andesitic) in the Mátra Mountains. The gabbro-basalts are accessible in various locations close to Eger (e.g. Szarvaskő). The andesitic lavas occur in different outcrops in the Mátra Mountains where the more alkaline magmatic rocks are rather scarce. ${ }^{7}$ Due to the carbonate deposits and volcanic activity, limnoquartzites, cherts, radiolarites and (to the northeast) obsidians also appear. ${ }^{8}$

As it is clearly visible from Fig. 1, the predominance of four types of raw materials (sandstones, conglomerates, quartz and gabbro) is almost evenly divided $(24 \%)$ with a slight excess of gabbro/gabbro-basalt ( $26 \%$, but it is only 3 items more than the others). This situation differs somewhat from other sites in Hungary and adjacent territories where this particular rock type is never dominant. ${ }^{9}$ This situation could be accounted for by proximity of gabbro (and metagabbro, basalt) outcrops. Moreover, Bükk Mountains (or more generally, the Hungarian-Slovakian border) are very often cited as the source of gabbroides. ${ }^{10}$ In the Neolithic this raw material was transported even more than $100 \mathrm{~km}$ to other sites. ${ }^{11}$

Based on these assumptions, the statement that this raw material is of local provenance seems to be the most probable. The Bükk Mountains are not the only region with gabbro-basalt outcrops. ${ }^{12}$ However, in the situation described, it is also unlikely that gabbro (or similar rock types) from the Apuşeni Mountains, for example, was brought to Apc. But it should be emphasized here that no decisive analysis (e.g. optical microscopy, chemical or magnetic susceptibility examination) was conducted to confirm the Apuşeni provenance of gabbro.

\footnotetext{
6 PlašienKa et al. 1997; VozÁr et al. 2002; PeliKÁn 2005; NÉMETH-PETHÖ 2009.

7 FÖLDVARY 1988; LESS 2011.

8 VOZÁr et al. 2002; PELIKÁN 2005.

9 E.g. STARNINI-SZAKMÁNY 1994, 1998; SZAKMÁNY-STARNINI 2002.

10 SZAKMÁNY 1996; SZAKMÁNY-STARNINI 2002.

11 SZAKMÁNY 1996

12 SZAKMÁNY-STARNINI 2002.
}

Andesite (the less abundant rock type in the collection $-2 \%=3$ items) is very often registered in the Mátra Mountains ${ }^{13}$ and this area is often suggested to be its source for various sites in Hungary and abroad..$^{14}$ This rock is certainly one of the local raw materials at Apc. Andesite is also described in the Tokaj-Slanec Mountains, ${ }^{15}$ but considering the abundance of this rock in the Mátra Mountains, its import seems unlikely.

Obviously in the archaeological sites located on the western side of the Mátra Mountains (an andesite-rich area) there are practically no andesite artefacts, and numerous basalt implements, although basalt comes from about $50 \mathrm{~km}$ east, from the Bükk Mountains. The technical characteristics of both rocks are comparable.

The two types of rocks distinguished here should be commented on. The sandstones and conglomerates differ on the basis of granulometric criterion (with a boundary of $2 \mathrm{~mm}$ ). However, it should be remembered that both could be sometimes identified in a single artefact. This is quite a typical situation in nature. The discrimination was done because petrographical accuracy requires it and, moreover, the technical quality of these two types of rocks is not the same.

Sandstone, conglomerates and quartz samples are certainly of local origin, coming from Mesozoic formations of the Bükk Belt. The outcrops of these rocks are numerous in the vicinity of Apc and in the Bükk Mountains. It should be emphasized that quartz from pebbles was used to produce only pestles.

The described rocks that were used to produce ground stone implements at the Apc archaeological site, despite their petrographical variety, all are suitable in terms of technology for their assumed functions (grinders, pestles etc.). All kinds of the aforementioned raw materials are hard, compact, and have grains (crystals) that increase their grinding properties and make them shock-resistant. The choice of these rocks seems to be quite obvious from a practical point of view: technologically perfect and easily available.

\section{The evolution of the lithic production at Apc}

On the evidence of pottery, all phases of the LBK were present at Apc: the early phase (Bicske-

\footnotetext{
13 E.g. FÖLDVARY 1988.

14 E.g. STARnini-SZAKMÁNY 1998; VARGA et al. 1975; SZAKMÁNY 1996; SZAKMÁNY-STARNINI 2002.

15 SZAKMÁNY-STARNINI 2002.
} 

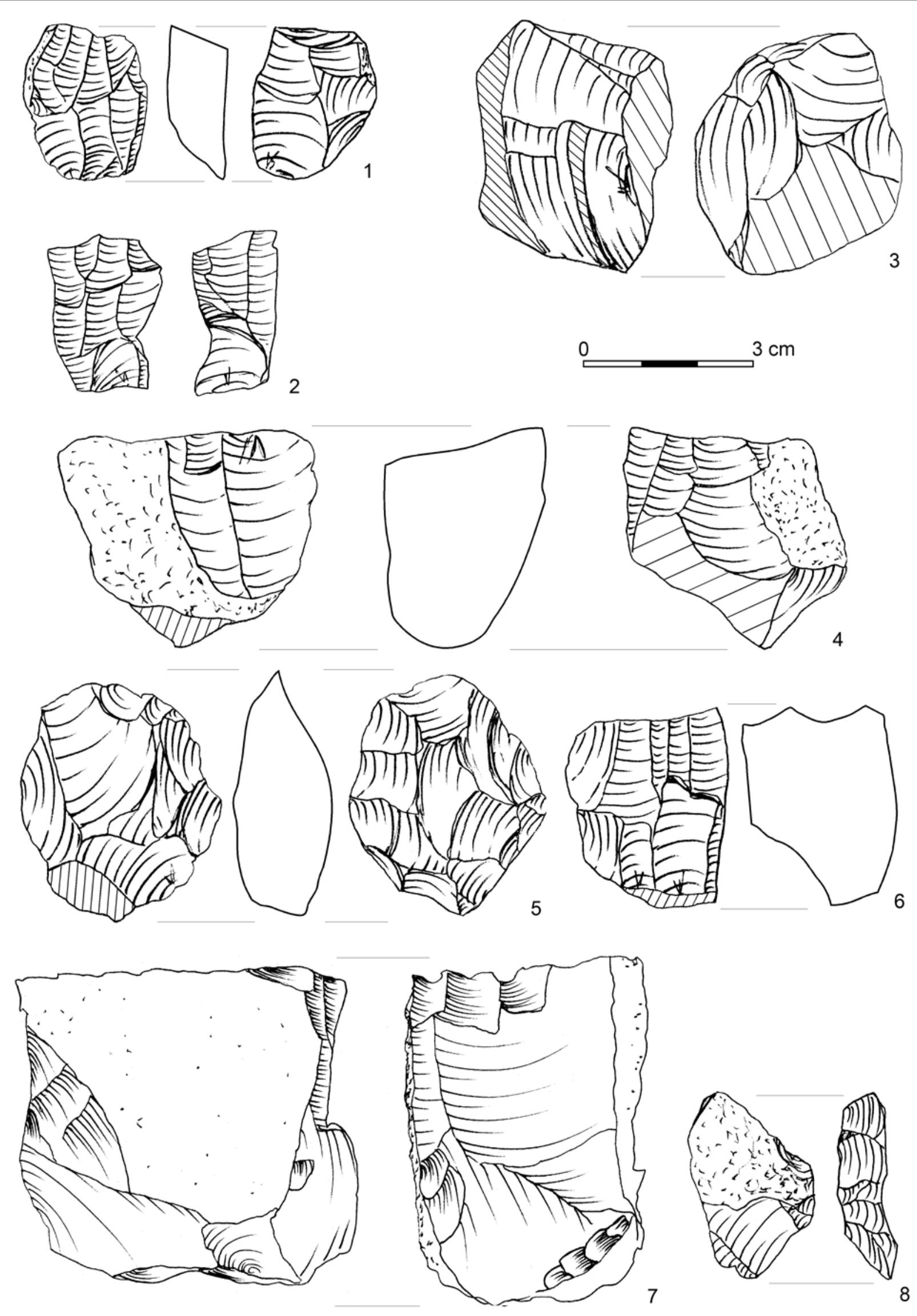

Fig. 2. Apc, phase I. 1-7: cores; 8: tablet

2. kép. Apc, I. fázis. 1-7: magkövek; 8: tablett 
Biňa) was rarely registered in closed assemblages, but later phases: Notenkopf and Želiezovce ceramics were found in many excavation units.

The oldest phase in the LBK assemblages (BicskeBiňa): Chipped stone industry

Assemblages of this phase are represented by features: 364, 419, 428, 454, 483, 506, 554, 598, 671, $697,814,910,915,919,926,932,1058,1284$. The assemblage consists of 135 chipped stone artefacts: 16 cores, 60 flakes, 10 blades, 7 tools, 26 chips and 16 indeterminate fragments.

\section{Cores}

The features of the oldest phase provided 16 cores. Predominantly they were from various types of limnoquartzites ( 9 cores - mostly types from Miskolc-Avas and the Cserhát Mountains), also of chalcedony and opals (7 cores). These cores were used for the production of flakes and blades. In terms of reduction sequences three groups can be distinguished:

a) 3 cores, in initial stage of exploitation, with flaking surfaces located on the broader face of a concretion, with a single-blow platform (feature 926; Fig. 2.4) or with three centripetal blows (feature 926; Fig. 2.3). In one case the core was shaped on a flat concretion with flake and blade scars on the narrower facet (feature 454; Fig. 2.7).

b) 3 double platform blade-flake cores with lateral preparation or preparation on the back. These cores are relatively small, reduction was conducted first from one platform, then from the opposite platform (features 454 - Fig. 2.6, 697 - Fig. 2.2, 919 - Fig. 2.1).

c) 4 cores that probably belong to group a but which in the final stage of reduction were transformed into subdiscoidal cores (feature 915 - Fig. 2.5).

Moreover, there were an indeterminate initial core, a fragment of a residual core and 4 small fragments of indeterminate cores.

\section{Blanks}

From the features of the oldest phase were recovered 60 flakes including two tablets of which one was struck off from the platform edge (Fig. 2.8), an overpassed flake, a trimming flake and a splinter.

The proportion of flakes in the oldest features is high, accounting for $44.4 \%$ of the entire inven- tory. This percentage suggests that, at least, part of the blank production was carried out at the site, which is evidenced by characteristic waste from core retrimming (such as tablets and trimming flakes). The series of flakes varies in size: length is between 13-56 mm, width between 11$47 \mathrm{~mm}$, thickness between $2-21 \mathrm{~mm}$. The most frequent are small specimens from 19-28 mm long, probably from advanced stages of core reduction, and a less numerous group, from 33-42 $\mathrm{mm}$ long, probably from preliminary stages.

Among the specimens with preserved butts (28), unprepared butts (7) or single-blow butts (12) predominate; moreover, there are dihedral (4), punctiform and linear butts (4). In one case the butt was prepared by a series of removals.

Partial cortex was registered on $23 \%$ of flakes; it should be added that only one flake was wholly cortical. 32 flakes had lateral cortex, two flakes distal cortex, and three flakes proximal cortex.

Analysis of the dorsal pattern shows that the majority of flakes come from different core reduction stages, core preparation or retrimming (the high proportion of specimens with perpendicular and centripetal scars).

Most flakes were made from a variety of limnoquartzites; next in number are flakes from chalcedony or opal. Of interest is a small obsidian flake found in feature 697.

Only ten blades $(7.4 \%)$ were registered in the oldest phase. These are:

- two obsidian blades: one from feature 697, the other from feature 932 . The former is a fragment of a regular blade detached from a core, with a carefully prepared butt and parallel edges, the latter is a very narrow, elongated $(42 \mathrm{~mm})$ slender blade detached from a core with a prepared platform;

- two blade fragments from limnoquartzites of unknown provenance, one was detached from a core with a single-blow platform (just as most flakes from limnoquartzite), the other was detached from a core with a single-blow platform. The width of the specimens is 14 and $15 \mathrm{~mm}$ respectively, the edges are parallel, straight;

- two fragments from opal: one is a proximal part of a blade detached from a core with a prepared platform and with regular parallel edges, the other is a small mesial part of a regular blade;

- a blade from brown radiolarite(?), $44 \mathrm{~mm}$ long, with a prepared butt and convergent edges (Fig. 3.1);

- two mesial fragments of blades from grey limnoquartzite; 


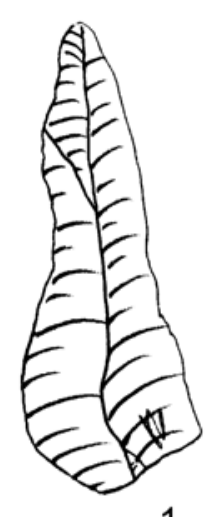

1

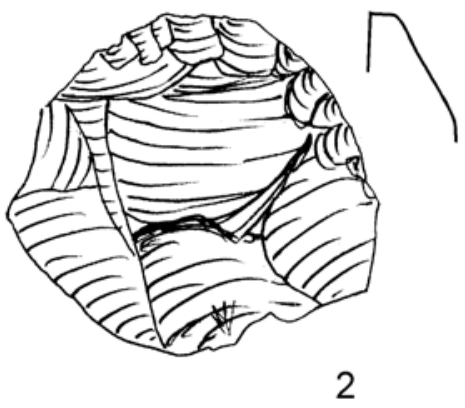

2

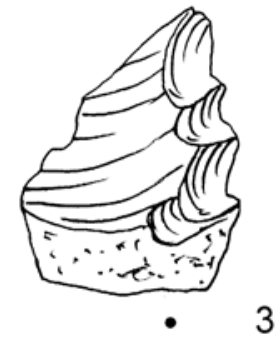

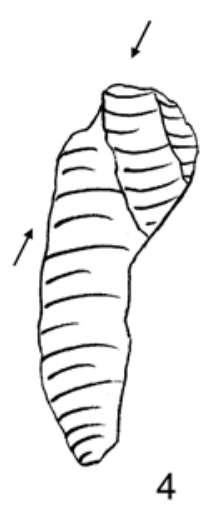

4
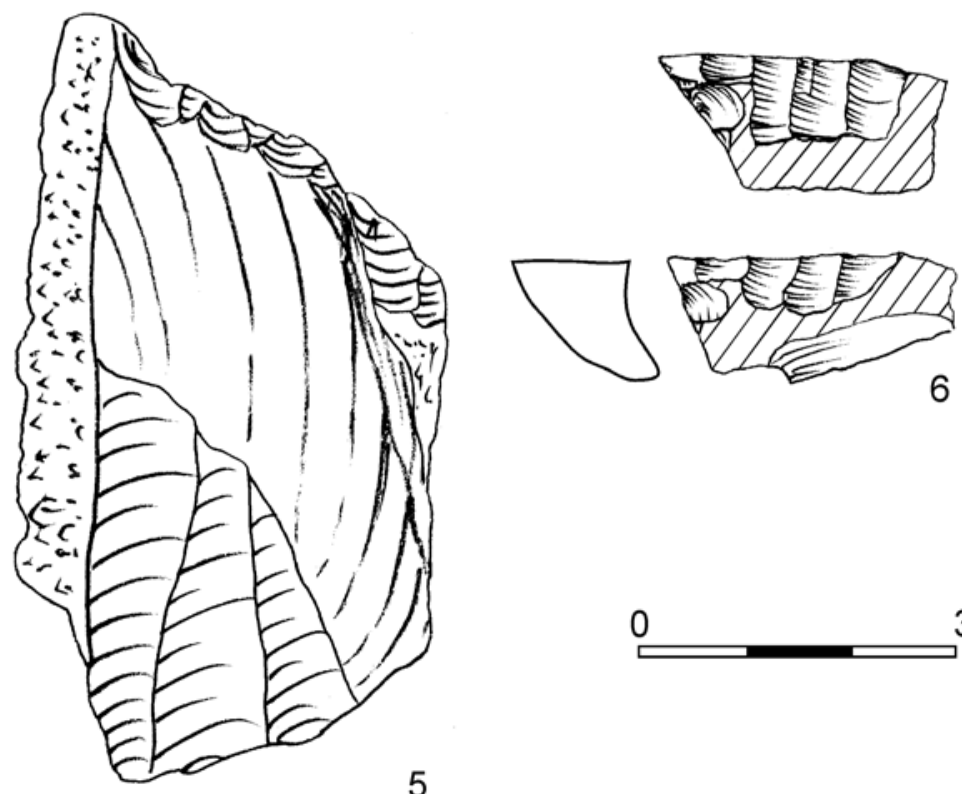

6
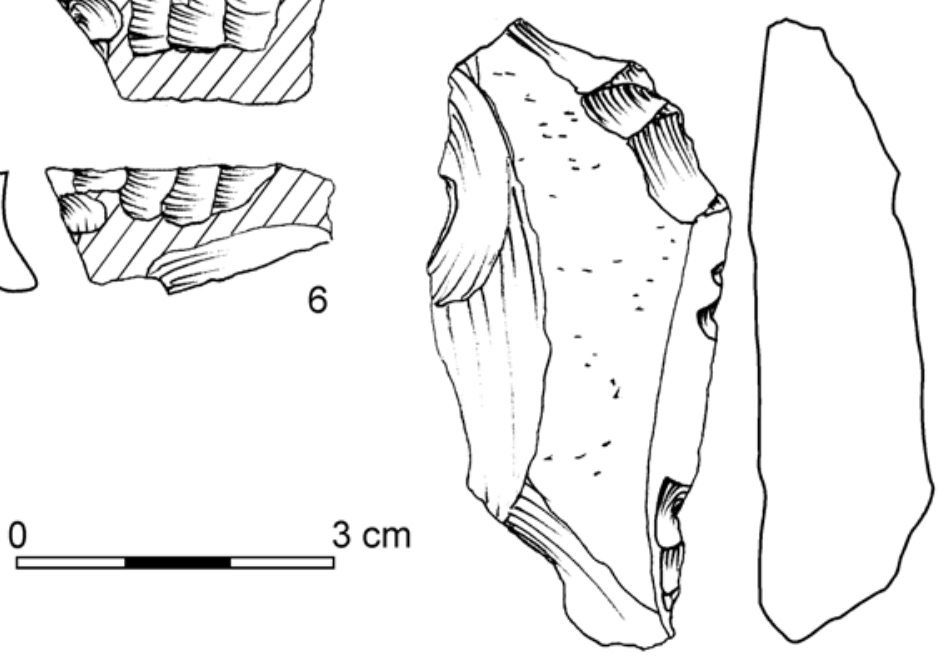

Fig. 3. Apc, phase I. 1: blade 2-7: tools

3. kép. Apc, I. fázis. 1: penge 2-7: eszközök

- a distal fragment of an overpassed blade with slightly convergent sides, from brown radiolarite.

The blades that have been wholly preserved are more than $40 \mathrm{~mm}$ long; their regular edges point to the high skill of knappers. Noteworthy is the presence of specimens with a facetted butt, which among flakes are rare. This suggests that the technique of blade removal was different from that used for flakes. On the other hand, at least some blades could have been brought from elsewhere. This is a more likely hypothesis especially in the case of blades from obsidian and radiolarite. Moreover, the inventory yielded 14 indeterminate fragments (possibly of flakes).

Of interest in phase I are 7 specimens, found in feature 419 , from grey-yellowish limnoquartzite originating from the southern part of the Mátra Mountains. Although the fragments do not make a refit yet, they probably come from the same raw material concretion.

In pits 419 and 697, a relatively large series of chips (26 specimens) was recovered. Their presence is noteworthy as they come from core reduction rather than tool production, and confirm the hypothesis about the local working of limnoquartzites. A chalcedony concretion shows attempts at breaking and two fragments from broken quartzite pebbles also occur.

In the group of blades, raw materials are represented that are sporadic among flakes, such as chalcedony, quartzite and a variety of limnoquartzites. 
Tools

From the features of the oldest LBK phase only seven tools were recovered, namely:

- an end-scraper on subdiscoidal flake, from brown-grey limnoquartzite (feature 506 - Fig. 3.2);

- a fragment of a retouched truncation on a blade with lateral cortex, from Cserhát Mountains type limnoquartzite;

- three notched-denticulated tools: one with lateral denticulated retouch, from limnoquartzite from the region west of Gyöngyös (feature 697 - Fig. 3.3), and two with oblique, transversal denticulated retouch (features 598 - Fig. 3.7 and 428 - Fig. 3.5); the former from banded limnoquartzite, the latter from silicified limestone;

- a flake with flat transversal retouch from red radiolarite (features 697 - Fig. 3.6);

- a fragment of an irregular blade used as a sickle insert from Cserhát Mountains type limnoquartzite (feature 926 - Fig. 3.4).

\section{General characteristics of Early Phase (Bicske-Biňa) chipped stone industry}

The assemblage is small, but it exhibits the characteristic features of local production mainly from limnoquartzites and opals/chalcedony, i.e. the raw materials that occur relatively near the site. It is this fact that makes Apc different from other pioneer LBK sites in new territories where, as a rule, imported raw materials were supplied from the initial territories of the LBK migration. ${ }^{16}$ For example, the people who migrated from Transdanubia to Moravia, Silesia and the Chełm region brought with them a supply of their own raw materials such as Szentgál type radiolarite or chocolate flint from the middle Vistula Basin. In the oldest phase at Apc, however, obsidian appears whose deposits are situated in the area of the Eastern (Alföld) Linear Pottery Culture.

The exploitation of local limnoquartzites necessitated a specific technique of blank production adapted to low quality raw materials, the technique that favoured flake, possibly also blade-flake, production. Blades are relatively rare, in all likelihood partly produced off-site. Basically, tools on blades are absent, except for a sickle insert on an irregular blade. which, again, is unlike on other sites of the Early Phase of the LBK where blade tools are most frequent. Moreover, the tools are dominated by notched-denticulated implements on flakes,

16 KACZANOWSKA 1985. whereas other sites of the LBK Early Phase are dominated by end-scrapers, truncations, trapezes and perforators made on regular, slender blades. Denticulated tools at Apc were used, first of all, for working wood (debarking, manufacture of small wooden items). Because the series of lithics is small, we cannot unequivocally determine whether the production technology and the tool structure are the consequence of the adaptation to local raw materials or the type of activities practiced by the first LBK inhabitants at Apc.

The oldest phase in the LBK assemblages (Bicske-Biña): Ground stone industry

The features of the early LBK provided 72 artefacts:

a) 12 fragments of ground stones with one polished surface made from: sandstone (4), breccia (2), quartzite (2), gabbro (1), basalt (2), and one from indeterminate rock. The fragments differ in size; they were probably quernstones or rubbers;

b) one fragment of a ground stone with two polished surfaces, from gabbro;

c) 18 flakes detached from ground stones made from: sandstone (1), gabbro (13), breccia (2), quartzite (1), and indeterminate rock (1);

d) nine fragments of lower grinding stones (features 1058, 1284 - Fig. 4). The working surfaces are flat or weakly concave along the horizontal axis: sometimes the base part is worked by pecking and then polished (Fig. 4.2). In some cases both surfaces were used (feature 598 - Fig. 5.1). The stones are made from andesitic porphyry (2), gabbro or andesite (4), breccia (3);

e) five fragments of upper (active) grinding stones from gabbro (features 697, 1284 - Fig. 5. $2,4)$, and 1 fragment of either the lower or the upper stone (feature 697 - Fig. 5.3);

f) three fragments of thin plaquettes, polished, from sandstone (2) and from gabbro (1).

g) three grinders made from quartz (1) and dacite (2) (feature 598 - Fig. 5.5);

h) five pounders from quartz or limnoquartzite pebbles (features 564, 697 - Fig. 6.1-2);

i) five pounders-grinders (feature 697 - Fig. 6.34) made from quartz (1), gabbro (2), quartzite (1), sandstone or gabbro (1). One of the specimens was broken along the horizontal axis, probably during use (feature 697 - Fig. 7);

j) six flakes from quartz pebbles (one pebble was used as a grinder);

k) five indeterminate fragments and one flake from a polished tool. 


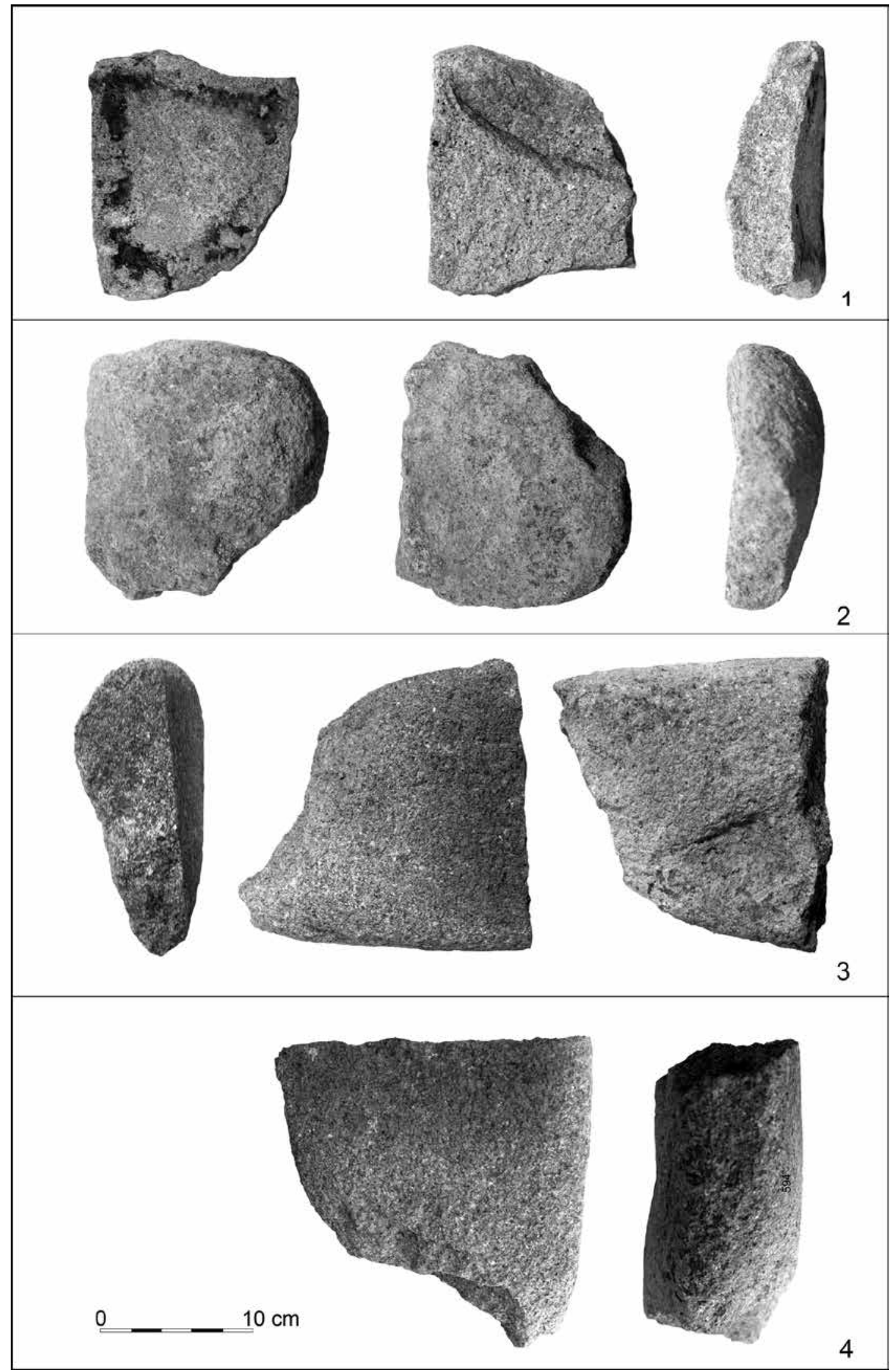

Fig. 4. Apc, phase I. 1-2: feature 1284, fragments of lower grinding stones; 3-4: feature 1058, fragments of lower grinding stones

4. kép. Apc, I. fázis. 1-2: 1284. objektum, alsó őrlőkövek töredékei; 3-4: 1058. objektum, alsó őrlőkövek töredékei 


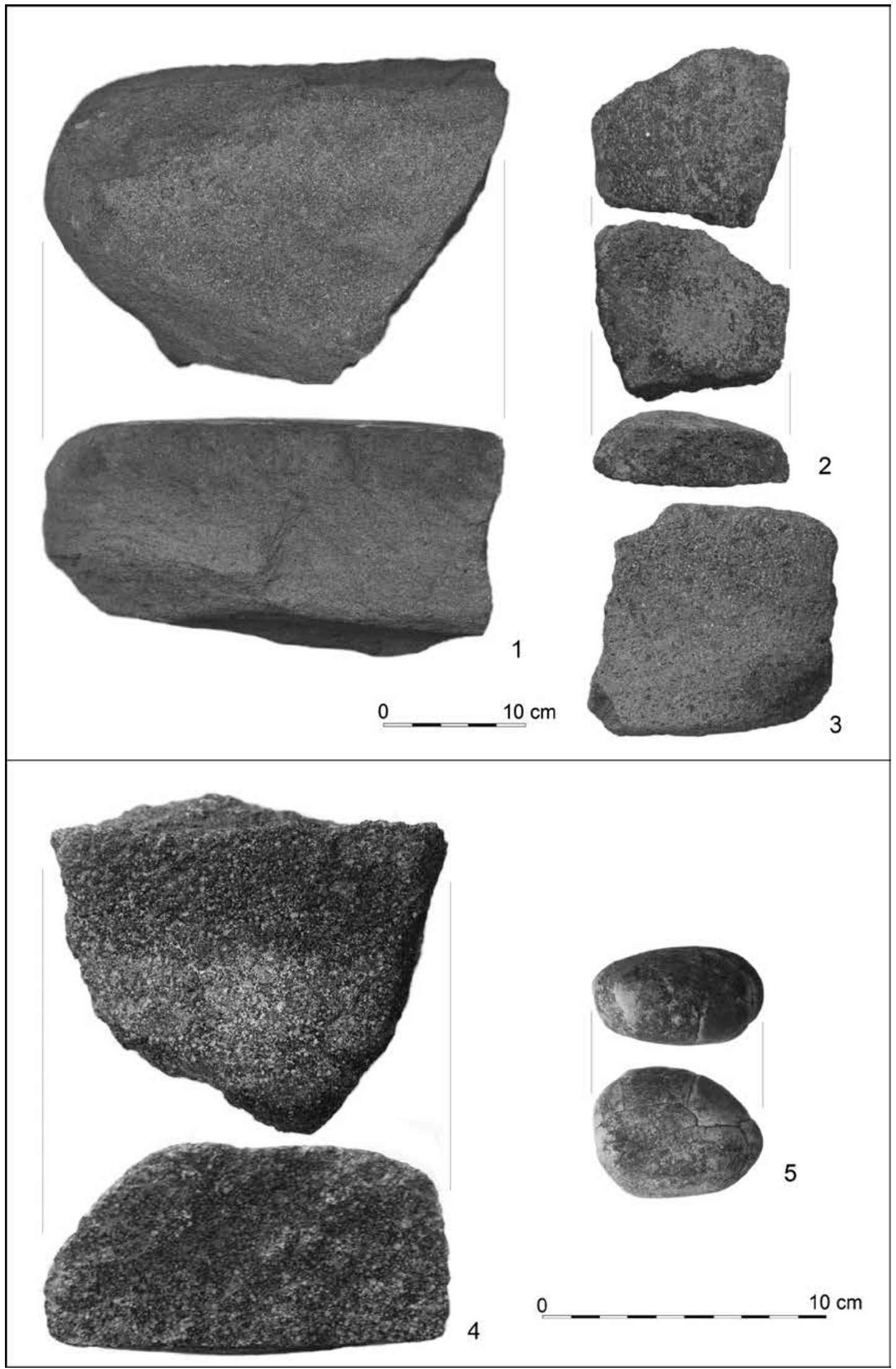

Fig. 5. Apc, phase I. 1: feature 598, fragment of lower grinding stone with two active surfaces; 2: feature 1284, fragment of upper grinding stone; 3-4: feature 697, fragments of upper grinding stone; 5 : feature 598, grinder

5. kép. Apc, I. fázis. 1: 598. objektum, két aktív felületú alsó őrlőkő töredéke; 2: 1284. objektum, felső őrlókő töredéke; 3-4: 697. objektum, felső őrlőkő töredékei; 5: 598. objektum, őrlőkő 


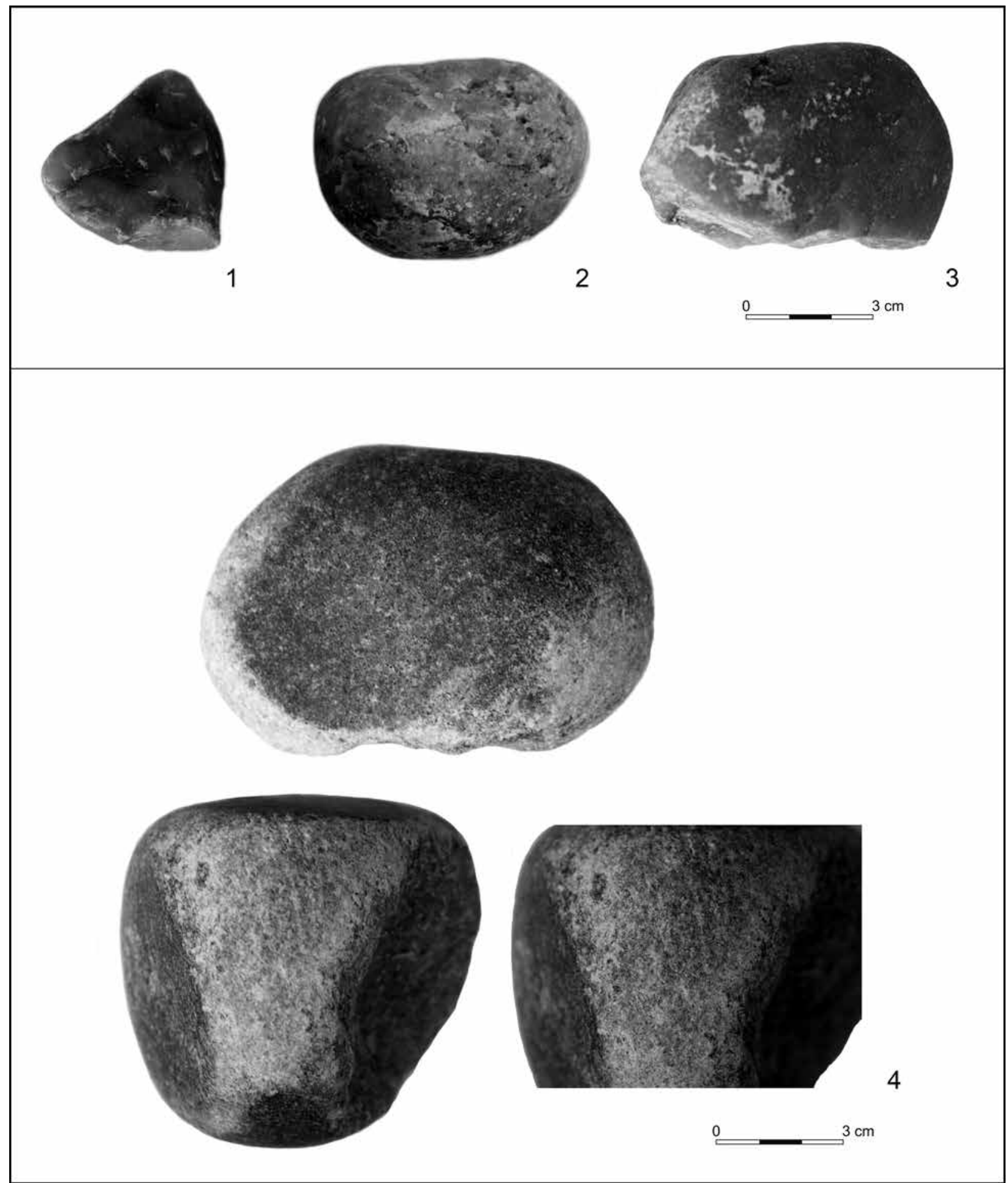

Fig. 6. Apc, phase I. 1: feature 564, hammerstone; 2: feature 697, pounder; 3-4: feature 697, pounders/grinders 6. kép. Apc, I. fázis. 1: 564. objektum, ütőkő; 2: 697. objektum, mozsártörő; 3-4: 697. objektum, mozsártörők/őrlőkövek

All the ground stones (with the exception of spherical pounders) have been preserved as fragments. The fragmentation is predominantly intentional. There were fragments of upper and lower grinding stones, pounders or grinders-pounders for crush- ing mineral dyes. Axes or adzes did not occur. Igneous rocks such as gabbro and andesite, and sedimentary rocks such as sandstone were represented. Occasionally, polished plaquettes were recovered that were probably used as rubbers. 
The middle phase of the LBK assemblages (Notenkopf): Chipped stone

The Notenkopf phase features are: 14, 40, 107, $111,167,210,273,275,290,471,476,529,561,612$, 613,1367 . The features contained exclusively, or almost exclusively, ceramic fragments with Notenkopf patterns; no sherds decorated with Želiezovce ornaments occurred.

From feature 107 chipped stone artefacts were recovered, including five cores, seven splintered pieces, 54 flakes, three blades, 16 tools, 17 chips, and five indeterminate fragments.

Just as in the oldest phase, the inventory is dominated by flakes; the proportion of cores is smaller. The distinctly higher tool index - which also includes blade tools - suggests that the structure of occupations of the inhabitants was somewhat different than in the previous phase. In all likelihood, on-site chipped stone working was still carried out which is confirmed by the presence of chips.

Majority of chipped stones from the Notenkopf phase were recovered from two features: 40 and 107. The remaining features provided only a few artefacts each.

Feature 40 contained a concentration of chips and flake fragments and two end-scrapers, whereas feature 107 yielded seven tools (nearly half of all the tools in this phase), 3 cores, 3 splintered pieces and numerous flakes.

\section{Cores}

Four cores were in the residual stage of reduction, only one in the initial stage:

a) a double platform core for flakes (or a changeof-orientation core) from cherry-coloured limnoquartzite with spots and bands; in the final stage of reduction the core became discoidal (feature 107 - Fig. 8.1);

b) an initial core from similar limnoquartzite, modified into a splintered piece;

c) a microlithic residual core from light-grey chalcedony;

d) a discoidal core from cherry-coloured limnoquartzite;

e) a fragment of a core in advanced phase of reduction.

\section{Splintered pieces}

There were seven splintered pieces:

a) a fairly regular, bipolar splintered piece, possibly the final stage of reduction of a

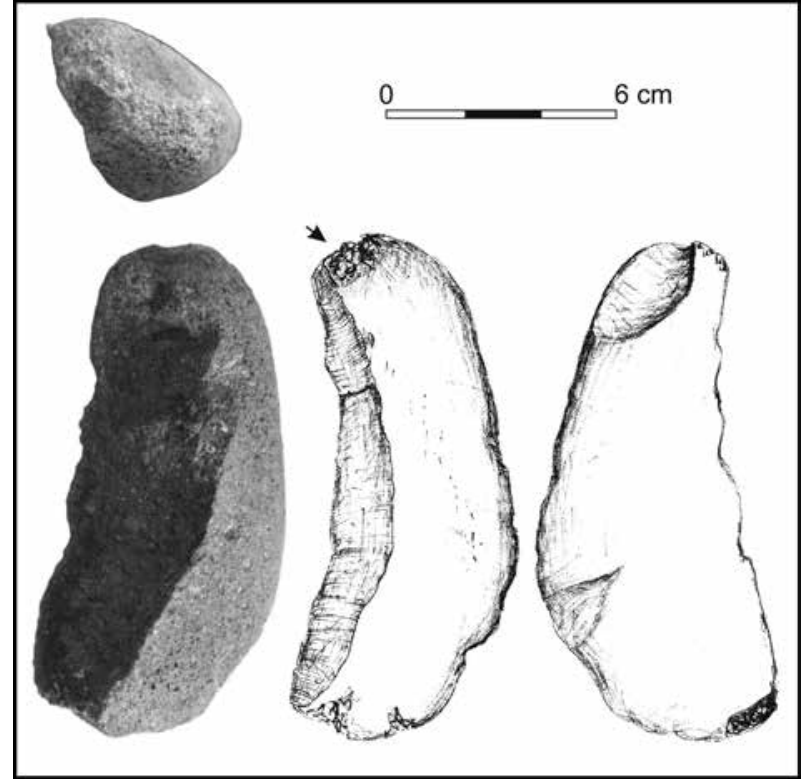

Fig. 7. Apc, phase I. feature 697, pounder/grinder

7. kép. Apc, I. fázis. 697. objektum, mozsártörő/őrlőkó

single-platform core for blades, the specimen is burnt (feature 107 - Fig. 8.4);

b) a fairly large splintered piece on a fragment of an axe-like polished tool from mudstone (feature 107 - Fig. 8.2);

c) five fine splintered pieces of which one is unipolar and one was made on a flake. The specimens were made from limnoquartzites, one is strongly patinated.

\section{Flakes}

54 flakes were recovered which is almost $50 \%$ of the inventory. The flakes are predominantly made from various types of limnoquartzites. Only two flakes are from jasper and three from opal. Moreover, a radiolarite flake was also recovered. Flake size varies considerably: flake length is between 14-67 mm, width between 10-76 mm, and thickness between 2-22 mm. In this phase the flakes are more robust in their proportions and larger than in the oldest phase.

Only 25 specimens have preserved butts. Just as in the oldest phase, the butts are single-blow (9), unprepared (7), linear/punctiform (8). One flake has a dihedral butt.

Dorsal cortex - on a larger or smaller area - occurs on $36 \%$ of the flakes. Lateral cortex is most frequent, covering up to half of the surface (7). The flakes with lateral cortex as well as flakes with distal cortex (5) come from initial stages of core reduction. The specimens with proximal 


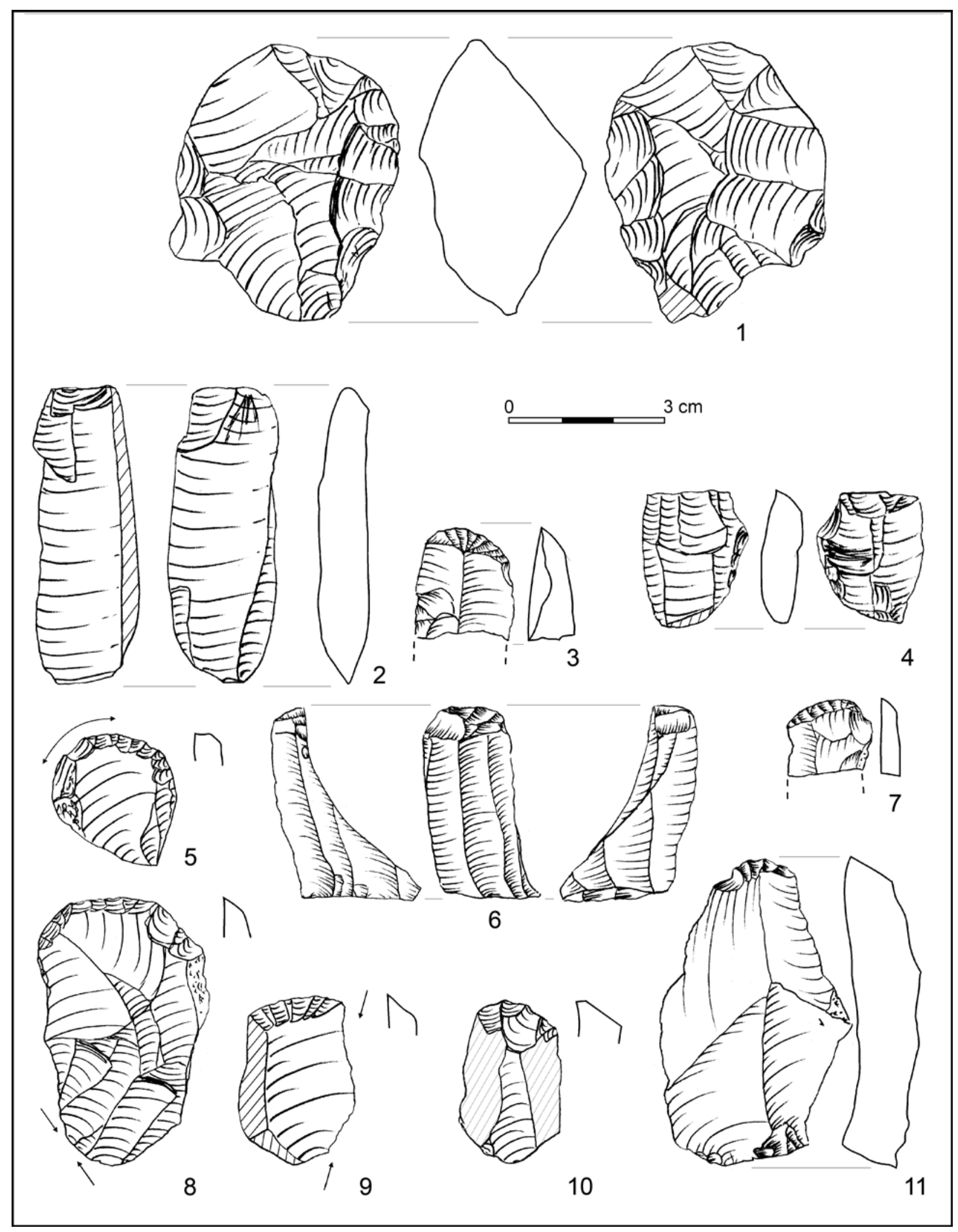

Fig. 8. Apc, phase II. 1: core; 2, 4: splintered pieces; 3, 5-11: tools

8. kép. Apc, II. fázis. 1: magkő; 2, 4: szilánkolódott darabok; 3, 5-11: eszközök 


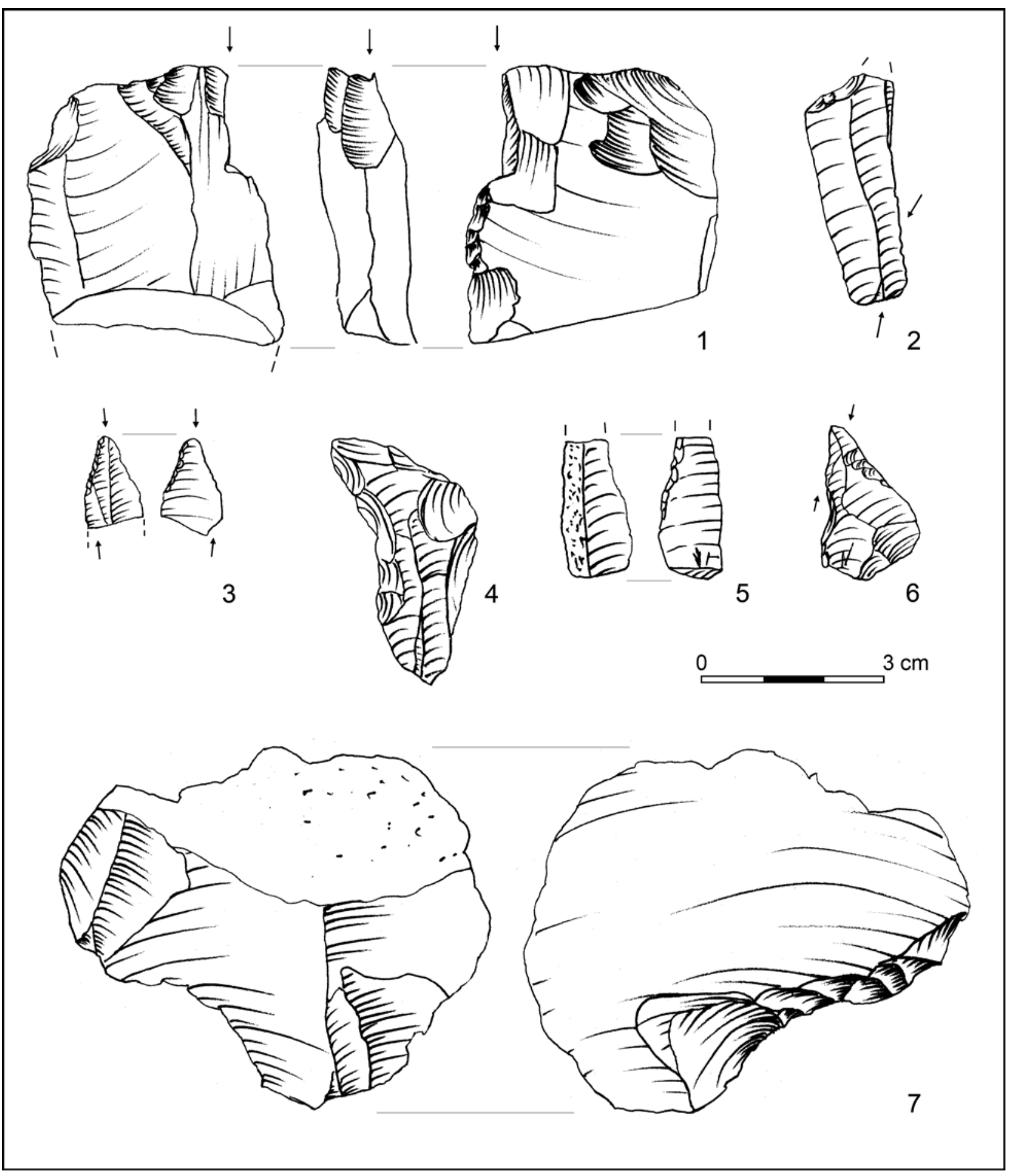

Fig. 9. Apc, phase II. 1-7: tools

9. kép. Apc, II. fázis. 1-7: eszközök 


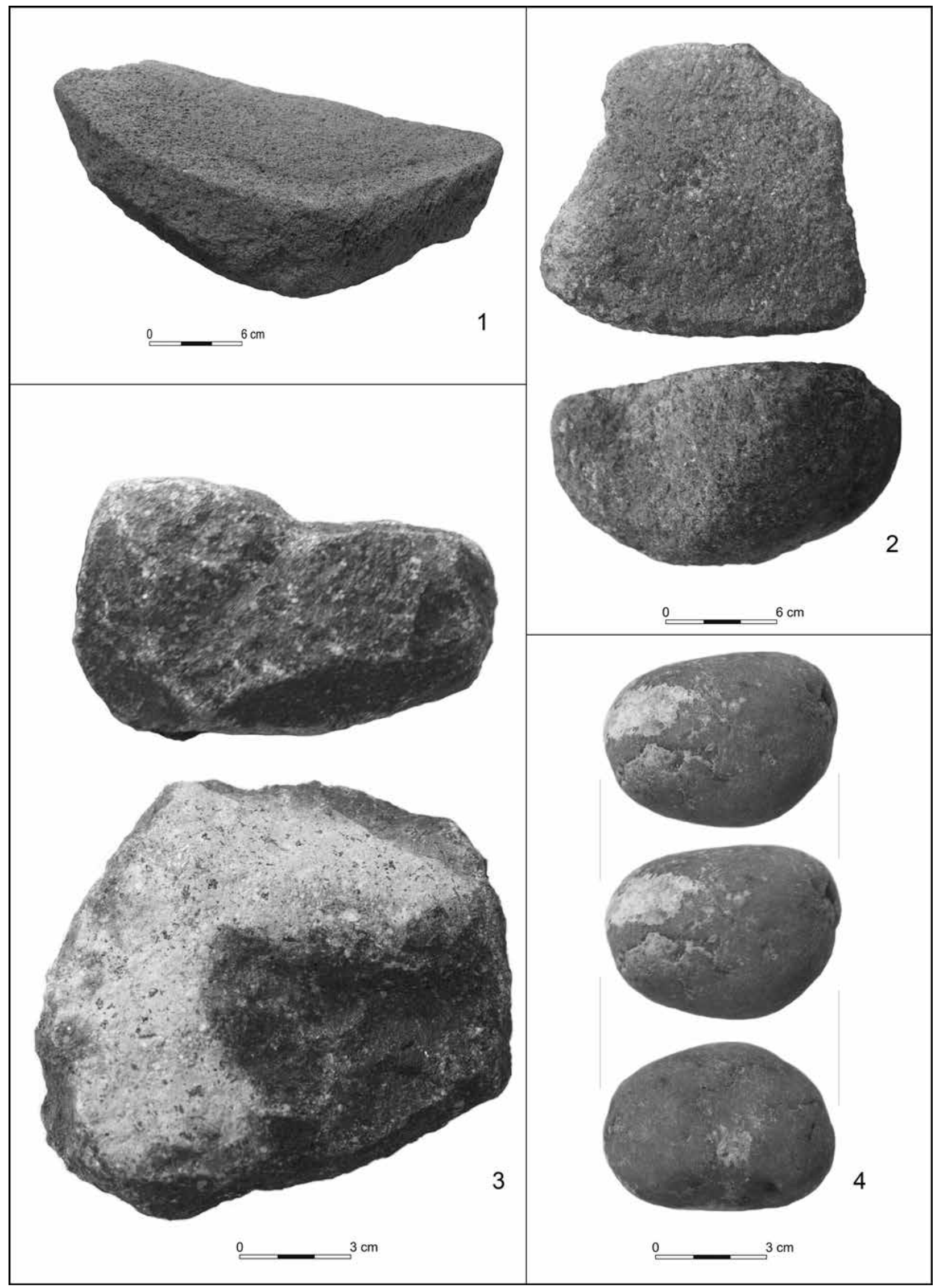

Fig. 10. Apc, phase II. 1: feature 111, fragment of lower grinding stone; 2: feature 273, fragment of upper grinding stone; 3: feature 275, fragment of andesite with traces of working; 4: feature 1367, hammerstone

10. kép. Apc, II. fázis. 1: 111. objektum, alsó őrlőkő töredéke; 2: 273. objektum, felső őrlőkő töredéke; 3: 275. objektum: andezittöredék megmunkálási nyomokkal; 4: 1367. objektum, ütőkő 


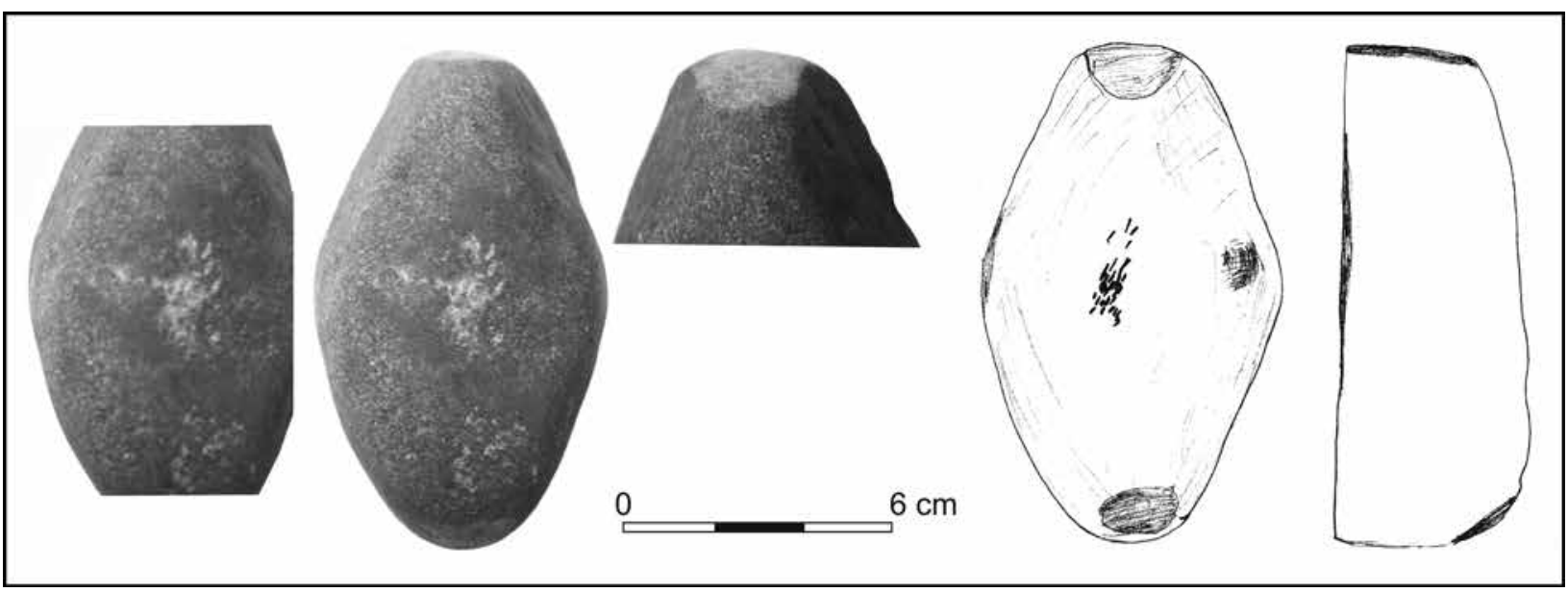

Fig. 11. Apc, phase II. Feature 111, polisher/hammerstone/retoucheur

11. kép. Apc, II. fázis. 111. objektum, csiszolókő/ütőkő/retusáló

cortex, proximal and distal or with a small cortex zone in the centre are rare. Two wholly cortical flakes were recovered.

Correlation between the presence of cortex on distal surfaces and the size of flakes has not been established. Analysis of the dorsal pattern of scars points to a minor role of preparation and retrimming in comparison with the oldest phase.

Tablets did not occur. A fragments of a flake struck off from the platform edge was also registered.

Despite the relatively numerous splintered pieces in the inventory, only one splinter was found. It can be assumed that the splintered pieces were not used for blank production but functioned as tools for e.g. cutting organic materials.

\section{Blades}

Some flakes were detached, probably, in the final stages of reduction of blade cores, which is confirmed by the presence of flakes with blade scars on the dorsal side (4). The proportion of blades is even lower than in the oldest phase (one intact blade and two fragments, all from limnoquartzite). The occurrence of blade tools is noteworthy (7 out of 16), made on regular blades with parallel edges. Except from limnoquartzites, blade tools were made from opals and one tool from radiolarite. It is difficult to decide whether these tools, or blades used for making them, had been produced within the settlement or elsewhere.

\section{Tools}

The tool inventory consisted of eight end-scrapers, one burin, one truncation, one microperfora- tor, two notched-denticulated tools, one bladelet with lateral retouch, one flake and one blade used as sickle inserts.

End-scrapers:

a) two distal fragments of end-scrapers on regular blades from limnoquartzite, possibly from the Mátra Mountains region (feature 40 - Fig. 8.3, 7);

b) an end-scraper on an overpassed blade from white, opaque siliceous rock of good quality (feature 529 - Fig. 8.6);

c) a short end-scraper on a blade-like flake used as a sickle insert (high gloss parallel to the edge), made from yellow, matt limnoquartzite (feature 107 - Fig. 8.9);

d) a short, subdiscoidal end-scraper on a flake, from light-grey limnoquartzite (feature 275 Fig. 8.5);

e) a short end-scraper from light grey limnoquartzite (feature 292 - Fig. 8.10);

f) a flake end-scraper with a narrow front, from Cserhát Mountains type limnoquartzite (feature 107 - Fig. 8.11);

g) an end-scraper on a large blade-like flake, with faint sickle gloss at the butt, from transparent chalcedony (Fig. 8.8).

\section{Burin}

- a lateral multiscar burin-on-a snap, made on a blade-like flake, from thick-grained, rough, white limnoquartzite (feature 613 - Fig. 9.1).

\section{Truncation}

- a distal, oblique truncation on a regular blade from red radiolarite. Sickle gloss in the proximal part indicates the use as a sickle insert (feature 613 - Fig. 9.2). 

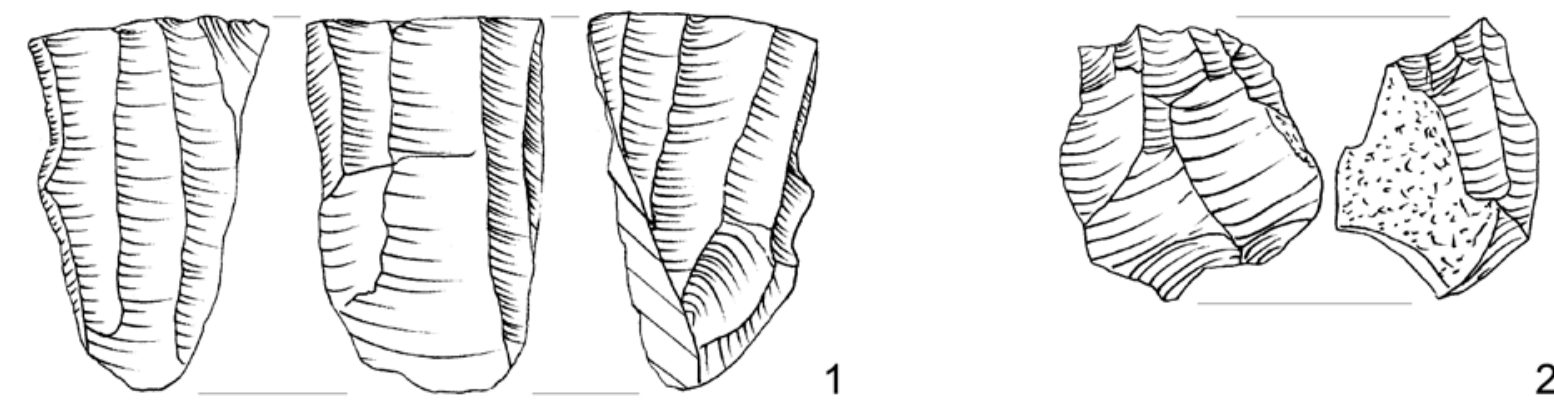

2
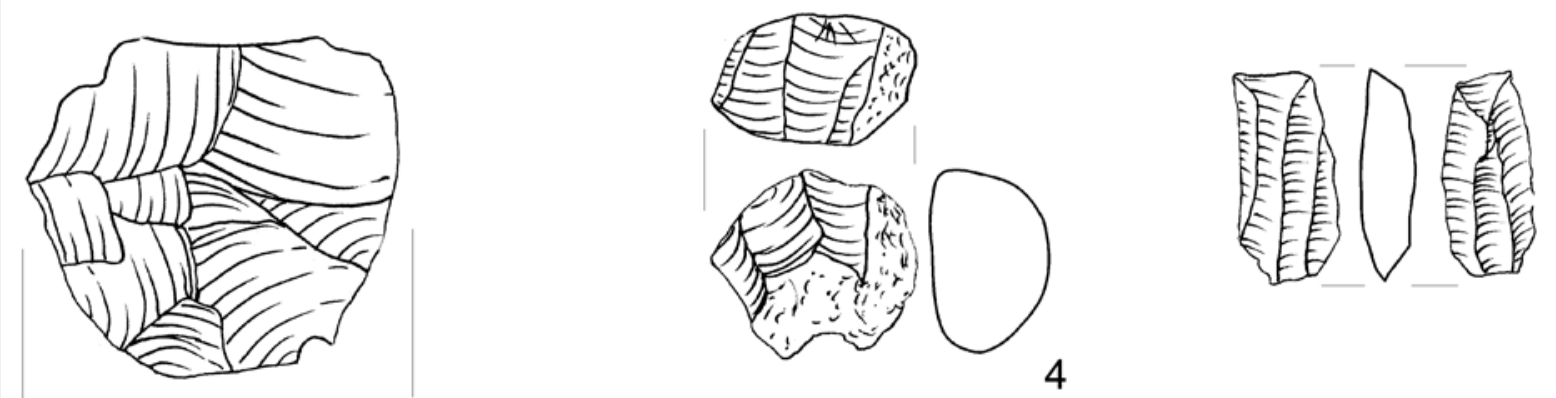

4
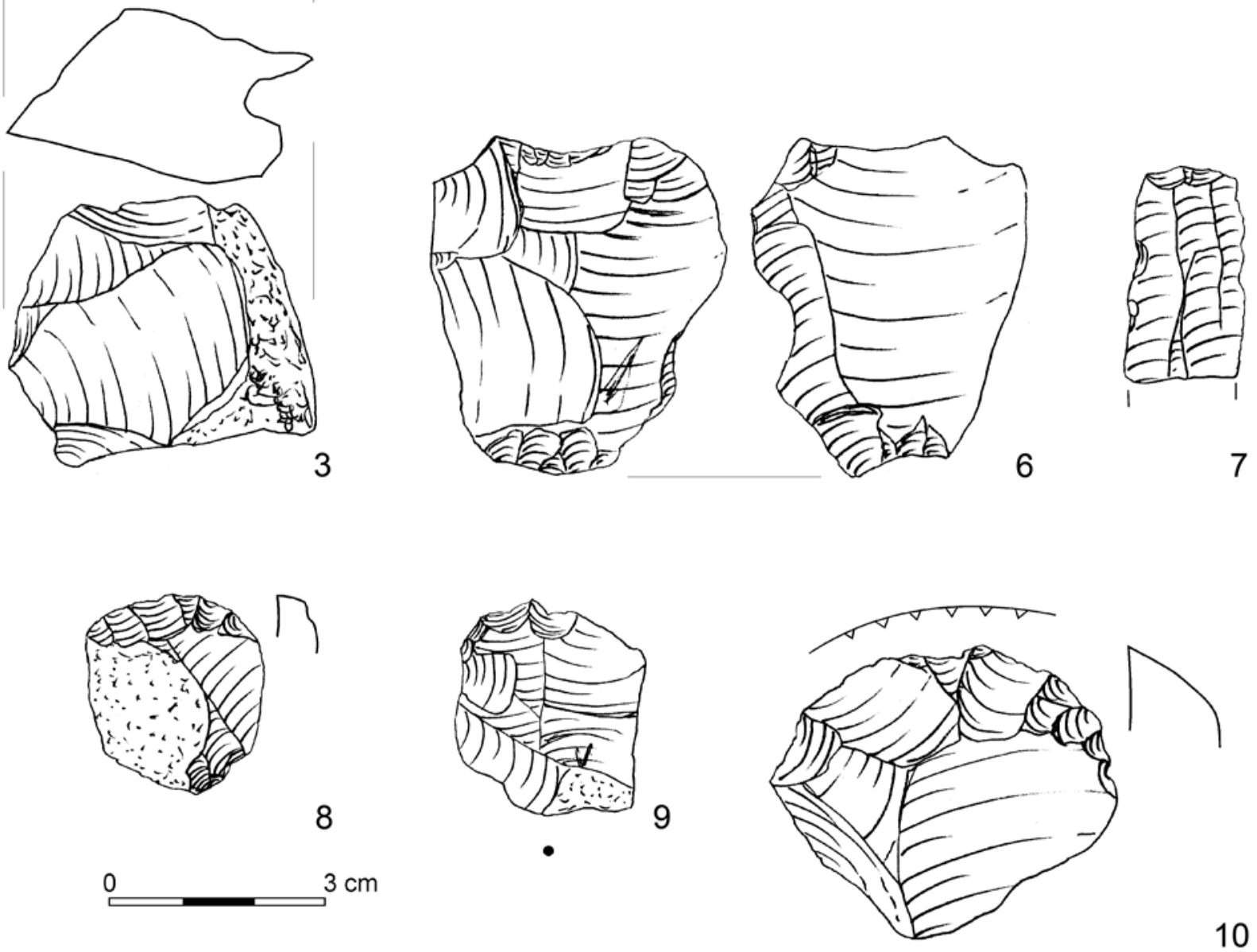

Fig. 12. Apc, phase III. 1-4: cores; 5-6: splintered pieces; 7-10: tools

12. kép. Apc, III. fázis. 1-4: magkövek; 5-6: szilánkolódott darabok; 7-10: eszközök 
Microperforator

- a distal fragment of an alternate perforator on a bladelet from limnoquartzite. The gloss on the lateral edge indicates the use as a sickle insert (feature 107 - Fig. 9.3).

Notched-denticulated tools

a) a flake with a retouched lateral notch, made from brown limnoquartzite, weakly transparent, with white spots and opaque intrusions (feature 471 - Fig. 9.4);

b) a large flake with distal cortex and proximal denticulated-notched retouch, from dark-grey and yellow-brown opaque limnoquartzite, probably from the southern part of the Mátra Mountains (feature 107 - Fig. 9.7).

\section{Retouched bladelet}

- a fine bladelet with partial inverse retouch on one lateral edge (feature 613 - Fig. 9.5), from limnoquartzite, similar to specimen of Fig. 9.4.

Unretouched sickle inserts

a) a flake with oblique gloss in the distal part, made from red radiolarite (feature 107 - Fig. 9.6);

b) a blade with oblique silica gloss, from limnoquartzite.

\section{General characteristics of the Notenkopf phase chipped stone industry}

The technology employed in the Notenkopf phase does not differ from that used in the oldest phase: flake cores, also double-platform, transformed into discoidal forms are present. Cores are more strongly reduced than in the early phase. Noteworthy is the smaller number of cores (5) than in the previous phase (12). The frequency of tools is higher $(14.9 \%)$ than in the oldest phase (5.2\%). End-scrapers, notably those made on blades are more important. Single tools appear that belong to categories which were not represented in preceding phase (a burin, a microperforator, a retouched bladelet). Denticulatednotched tools on flakes play a smaller role in the Notenkopf phase. Obsidian artefacts that occur in the oldest phase are absent.

The middle phase of the LBK assemblages (Notenkopf): Ground stone implements

The features from the Notenkopf phase provided 31 ground stone implements: a) five fragments with one polished surface, from andesitic porphyry (2), from sandstone, breccia or gabbro (1 each);

b) a fragment with two polished surfaces, made from andesitic porphyry;

c) six flakes from ground stones from finegrained sandstone with mica, from gabbro, and from burnt or indeterminate rocks;

d) a fragment of the lower grinding stone from gabbro, the base part was worked by pecking (feature 111 - Fig. 10.1);

e) a half-product of a lower grinding stone from gabbro;

f) a fragment of a lower or an upper grinding stone from andesite;

g) a fragment of the upper grinding stone from gabbro (feature 273 - Fig. 10.2);

h) three plaquettes with polished surfaces, one is polished on both sides, made from shale, finegrained sandstone with mica, and andesite;

i) three hammerstones from quartz and quartzite pebbles (feature 1367 - Fig. 10.4) and a fragment of a hammerstone from quartzite;

j) polisher/hammerstone/retoucher from quartz with traces of red mineral dye (feature 111 Fig. 11).

Moreover, there were six chunks from sandstone and andesite, a large fragment with traces of working, from andesite (feature 275 - Fig. 10.3), and 2 fragments of broken pebbles, from andesite and from quartz.

The groundstones are basically similar to those in the oldest phase. The inventory contained fragments or flakes from quernstones, a fragment of a half-product, polished plaquettes, and hammerstones less numerous than in the early phase. Similar raw materials derived from deposits relatively near the site were used.

The late (Želiezovce) phase of the LBK: Chipped stone industry

To the late phase belong features $4,44,68,69,70$, $75,76,77,103,106,108,162,164,165,168,207$, $218,268,272,414,430,468,472,473,555,609,615$, $638,720,762,763,819,826,1354,1368,1375,1378$, 1394. The features provided ceramics decorated with Želiezovce ornaments, often in association with sherds of Notenkopf ceramics. Several features provided, altogether, 138 chipped stone implements: cores (13), splintered pieces (4), flakes (79), blades (15), retouched tools (17), chips (8), and undetermined fragments (2). 


\section{Cores}

Cores in the Želiezovce phase are in advanced stages of reduction and the majority are residual specimens. Only one core, from transparent chalcedony, is a regular subconical blade core with the flaking face around the whole circumference and scars from regular blades (feature 414 - Fig. 12.1). A residual, double-platform blade-flake core with a common flaking surface was made from brown Miskolc-Avas type limnoquartzite (feature 473 - Fig. 12.2).

Among other cores belong:

a) two residual, single-platform microlithic cores from limnoquartzite (feature 638 - Fig. 12.4) and a burnt specimen;

b) two fragments of single-platform cores for blades, one from transparent chalcedony, the other from limnoquartzite;

c) three discoidal flake cores from white limnoquartzite and Cserhát Mountains type limnoquartzite (feature 615 - Fig. 12.3);

d) two polihedral-spherical cores for flakes, one from brown limnoquartzite, the other from jasper of unknown origin;

e) two fragments of indeterminate cores, from Cserhát Mountains type limnoquartzite and from dark brown limnoquartzite.

\section{Splintered pieces}

The four splintered pieces are:

a) two splintered pieces on cores, fairly small, bipolar and bifacial (feature 472 - Fig. 12.5); one is from white limnoquartzite, the other from Cserhát Mountains type limnoquartzite;

b) two specimens on fairly large flakes, also bipolar, probably unifacial (feature 168 Fig. 12.6), one is from Cserhát Mountains type limnoquartzite, the other from brown limnoquartzite.

\section{Flakes}

The group of 79 flakes included three small splinters. In comparison with preceding phases a greater variety of exploited raw materials can be seen. Except the predominant limnoquartzites, there were flakes from obsidian (2), from jasper (2), from opal (11), from greenstone and tuffit (2 each). Moreover, a flake from metamorphic rock was also recorded. Flakes made from these latter raw materials were detached during the production or use of ground or polished stone implements.
Flake length is between $25-60 \mathrm{~mm}$, the most numerous group is in the length mode of 20-35 $\mathrm{mm}$, width is between 14-51 mm (the broadest specimens were detached from polished artefacts). Flake thickness is between 3-21 mm.

Just as in the preceding phases, unprepared butts (7) predominate followed by single-blow butts (8). Linear and punctiform butts are relatively frequent (9), other types such as dihedral (2) and facetted butts (1) occur sporadically.

A relatively small number of flakes show dorsal cortex $(15 \%)$. This is the lowest index of cortical flakes in all the LBK phases at the site. The presence of wholly cortical flakes (5) is noteworthy. These flakes are fairly large (length is between 29-45 $\mathrm{mm}$ ), the butts are unprepared, which suggests that they were detached in the first stages of decortication. Various types of limnoquartzites are represented.

The dorsal patterns are predominantly unidirectional scars (13), the perpendicular pattern of scars comes next. These flakes come from preparation or change of orientation of cores.

The technique of flake removals produced, as a rule, flat bulbs. A large number of flakes are with blade scars or blade and flake scars on the dorsal face.

\section{Blades}

Only 15 blades were recovered from the features of the Želiezovce phase, accounting for $10.8 \%$ of the inventory. This is a small proportion but, nevertheless, the highest from all the phases. 7 blades have been wholly preserved, the remaining blades are fragments.

Majority are specimens from limnoquartzites (6). Some are burnt and the raw material cannot be identified (3). One blade from red jasper, two blades from transparent chalcedony and two from fine-grained rock were recovered. Of interest is a large overpassed blade from obsidian. Just as in the preceding phases, among blades there are more meso- and extralocal raw materials than among flakes.

Blade length is between 22-60 mm, width between 8-25 mm. The lateral sides of blades are parallel, the profiles are straight. Among the preserved butts, six were single-blow, two were facetted and one was linear. It should be added that in the tool group six specimens were made on blades of which two were sub-crested. As a rule, blade tools were made on much longer blades than unretouched specimens. 


\section{Tools}

The Želiezovce phase yielded 17 tools: end-scrapers (7), burins (2), a perforator, a truncation, notched-denticulated tools (3), a sub-crested blade with lateral retouch, sickle inserts (2).

End-scrapers:

a) a blade specimen with a weakly distinguished distal front, from mudstone (feature 103 - Fig. 12.7).

The remaining specimens are short end-scrapers on flakes:

b) an end-scraper from Cretaceous Dniester flint, with a weakly convex, fairly steep front (feature 762 - Fig. 12.8);

c) a specimen from brown limnoquartzite, with an irregular, denticulated front (feature 472 Fig. 12.9);

d) two specimens: one from brown limnoquartzite, the other, with lateral retouch, is made from brownish limnoquartzite with white spots (feature 168 - Fig. 13.1 and 430 Fig. 13.3);

e) a very short, fan-shaped end-scraper from yellow limnoquartzite (feature 473 - Fig. 13.2);

$f$ an end-scraper on a large flake, with a fan-like front, well worn, with microscars, made from white opal (feature 70 - Fig. 12.10).

Burins

- two mesial, polihedral burins on thick blades, one from quartzite, the other from transparent chalcedony (feature 106 - Fig. 13.4 and 609 - Fig. 13.5).

\section{Perforator}

- a slender perforator with an elongated tip, made on a regular blade from jasper originating from the Mátra Mountains (feature 168 - Fig. 13.6).

\section{Truncation}

- a truncation on a slender blade with a distal, weakly retouched notch; made from white opal (feature 70 - Fig. 13.7).

\section{Notched-denticulated tools}

This group of tools is represented by 4 flake specimens, fairly regular:

a) with bifacial denticulated retouch on the entire circumference, made from brown limnoquartzite (feature 473 - Fig. 13.8);

b) a specimen with denticulated retouch on the entire circumference; made from white opal (feature 70 - Fig. 13.10); c) a specimen with partial denticulated inverse retouch on one lateral side; made from Jurassic flint from the Kraków-Częstochowa Plateau (feature 763 - Fig. 13.9).

Also present was a sub-crested blade-flake with partial, flat lateral retouch, made from cherry-coloured limnoquartzite (feature 763 - Fig. 13.12).

\section{Sickle inserts}

Two specimens, one on a blade, the other on a blade-flake, with distal sickle gloss, made from limnoquartzite (feature 103 - Fig. 13.11).

\section{General characteristics of the Želiezovce phase chipped stone industry}

The overall picture of blank production technique and the raw materials composition does not markedly differ from the preceding phases. Besides extralocal obsidians, one specimen from Jurassic flint from the Upper Vistula region and one end-scraper on Cretaceous flint from the Dniester basin were recovered.

In the group of cores there is only one regular, subconical, single-platform core for blades, the remaining specimens are flake cores, strongly exhausted, subdiscoidal or polihedral-spherical. The absence of blade cores contrasts with the presence of blades $(10 \%)$ and blade tools, often on large blades. This suggests off-site production of blades - at least some of them. The tool structure is in part similar to that from the Notenkopf phase (the domination of end-scrapers), whereas tool types appear that were unknown in the earlier phases such as e.g. slender polihedral burins or a perforator, both on blades.

The late (Želiezovce) phase of the LBK: Ground stone artefacts

118 ground stone artefacts and fragments were recovered, namely:

a) eight fragments with one polished surface (4 from sandstone, 1 from quartzite, 3 from various igneous rocks);

b) three fragments with two polished surfaces, from sandstone and andesite;

c) three fragments of lower grinding stones, from andesite and gabbro;

d) a half-product of a lower grinding stone from sandstone (feature 76 - Fig. 14.1);

e) a fragment of a lower or an upper grinding stone (burnt); 


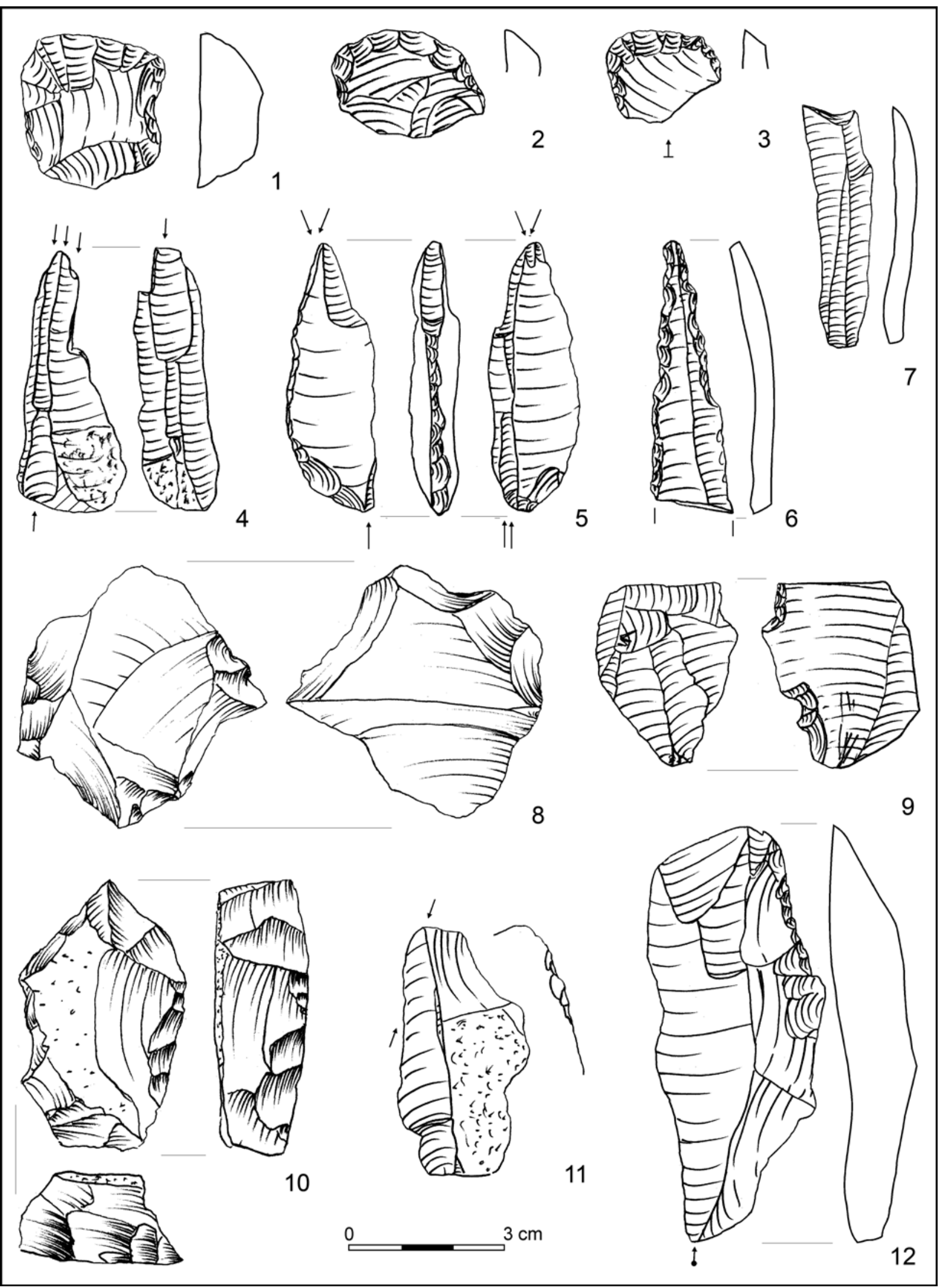

Fig. 13. Apc, phase III. 1-12: tools

13. kép. Apc, III. fázis. 1-12: eszközök 


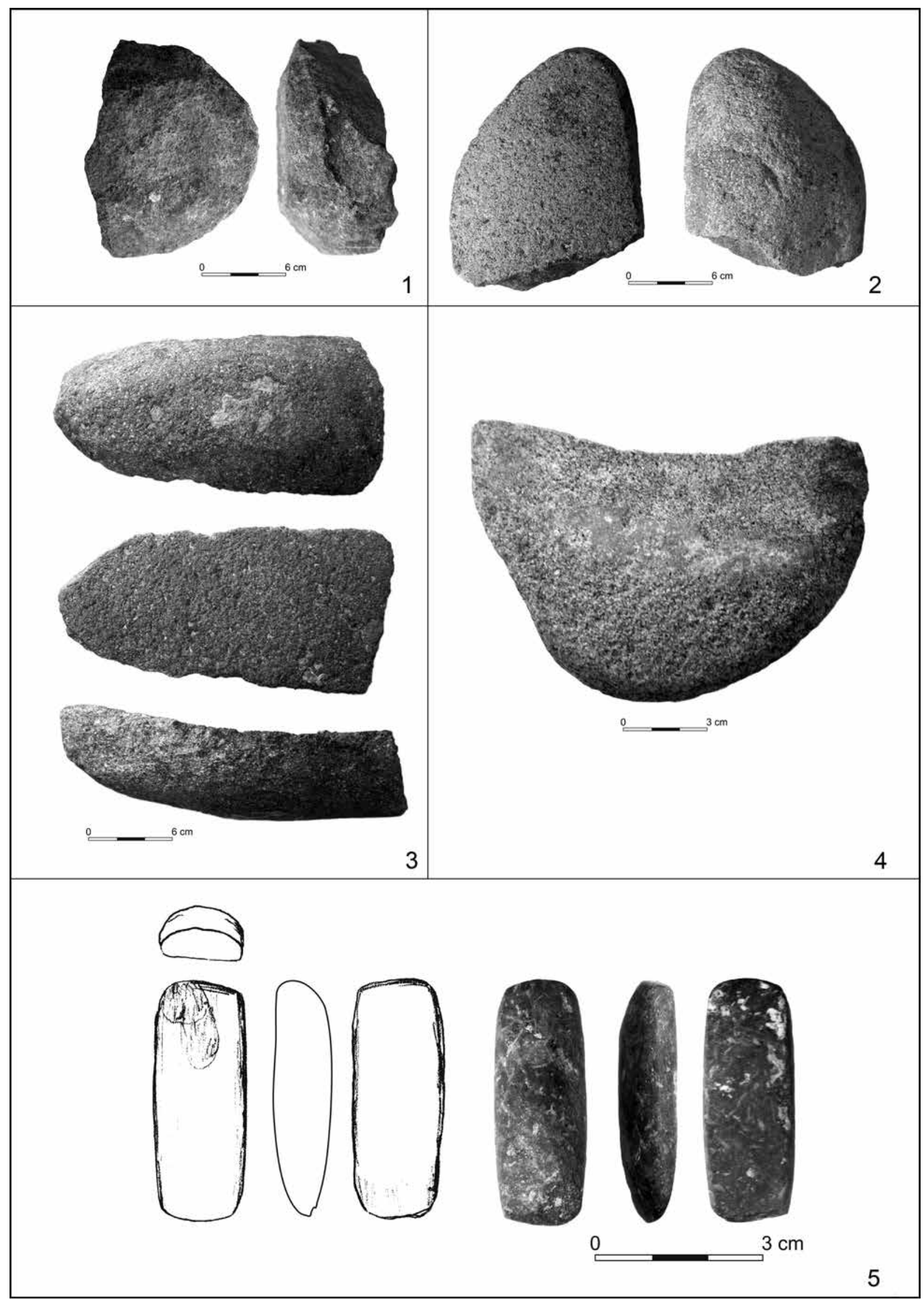

Fig. 14. Apc, phase III. 1: feature 76, half-product of grinder; 2: feature 162, fragment of upper grinding stone; 3: feature 615, fragment of upper grinding stone; 4 : feature 207, fragment of upper grinding stone; 5 : feature 720 , polished axe

14. kép. Apc, III. fázis. 1: 76. objektum, őrlókő-féltermék; 2: 162. objektum, felső őrlőkő töredéke; 3: 615. objektum, felső őrlőkő töredéke; 4: 207. objektum, felső őrlőkő töredéke 5: 720. objektum, csiszolt balta 
f) 14 fragments of upper grinding stones, from gabbro (8), sandstone or breccia (4), one fragment is burnt (features 162, 207, 615 - Fig. 14.2-4);

g) 28 hammerstones (feature 4, 207, 1368 - Fig. 15.1-2 - of which one is two-ended with traces of red dye - feature 207 - Fig. 15.3) and hammerstones-grinders (circumferential - feature 615 - Fig 15.4, two-ended - feature 763 - Fig. 15.5), made from quartz (13), quartzite (3), gabbro (5), opalite (2), and other igneous rocks (2);

h) 12 plaquettes with polished surfaces, from sandstone (10) and gabbro (2);

i) a polisher from indeterminate rock;

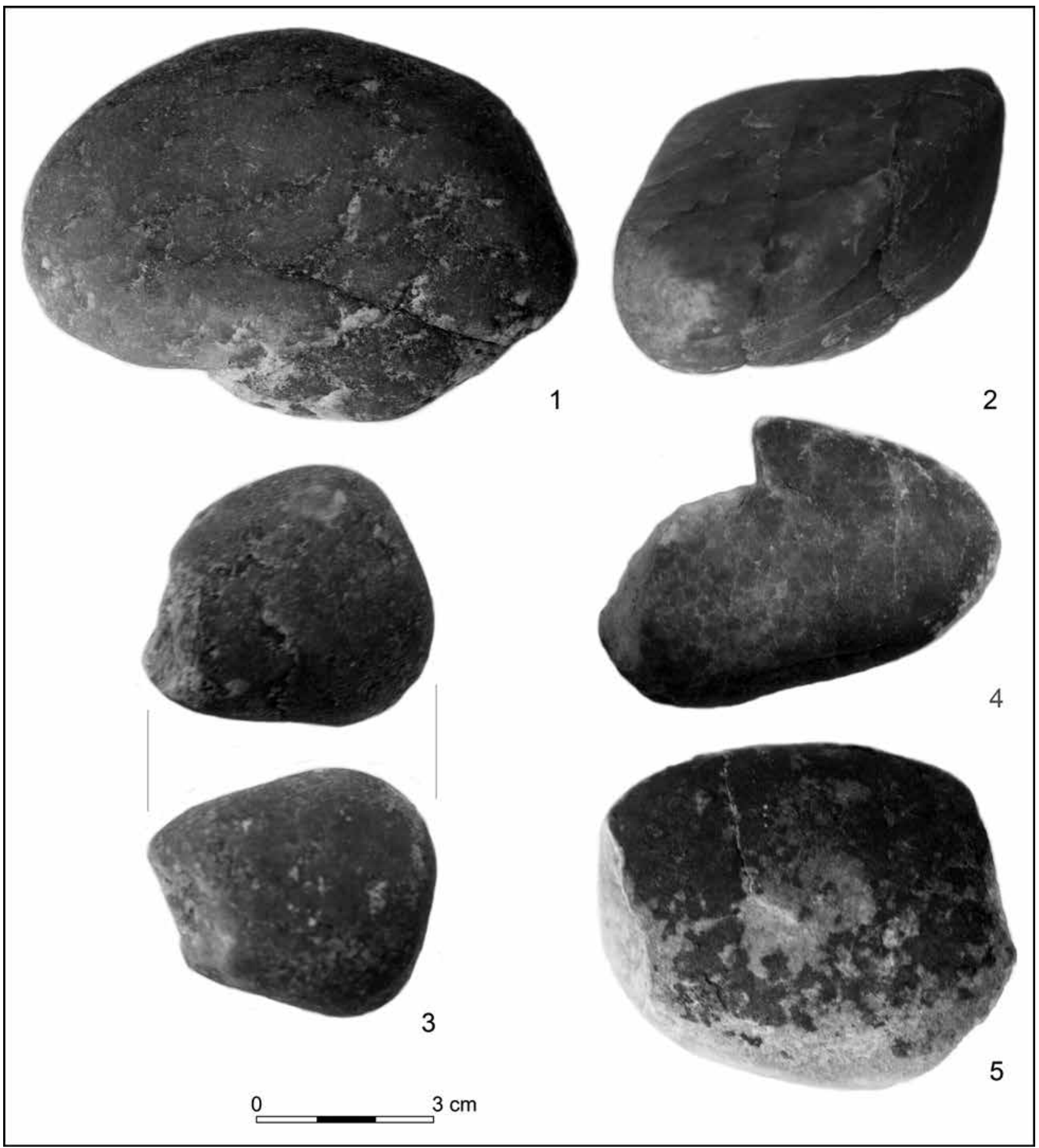

Fig. 15. Apc, phase III. Hammerstones, 1: feature 4; 2: feature 1368; 3: feature 207; 4: feature 615; 5: feature 768

15. kép. Apc, III. fázis. Ütőkövek, 1: 4. objektum; 2: 1368. objektum; 3: 207. objektum; 4: 615. objektum; 5: 768. objektum 
j) 11 broken pebbles from quartz (9) and gabbro (2);

k) 19 flakes from ground stones, from gabbro (8), fine-grained sandstone (1), andesite (5), coarse-grained sandstone (4), and a burnt specimen;

l) 14 chunks probably from ground stones.

Moreover, a miniature axe from black shale (feature 720 - Fig. 14.5) and two flakes from polished tools from black-green shale were recovered.

In the Želiezovce phase ground stones are more numerous, but hammerstones and plaquettes (grinders?) predominate, whereas fragments of quernstones, notably of upper (active) grinding stones, are relatively less frequent. The exploited raw materials were similar to that used in earlier phases. Some quernstones are produced on-site, which is evidenced by a fragment of a half-product of a quernstone from sandstone.

\section{Conclusions}

The site of Apc is situated at the eastern peripheries of the LBK, closest to the settlement agglomeration of this unit in the surroundings of Budapest ${ }^{17}$ which is separated from the agglomeration of LBK sites in Transdanubia by a sparsely inhabited zone. From the east of the Danube and the Tisza interfluve is, too, a sparsely inhabited zone separating the LBK from the Eastern Linear Pottery Culture. ${ }^{18}$ The largest LBK site in the vicinity of Apc is the site of SzécsényÜltetés. ${ }^{19}$

The most objective index of contacts maintained by the inhabitants of Apc in the LBK period are lithic raw materials exploited throughout the time-interval of the functioning of the settlement. The most frequently exploited raw materials were limnoquartzites and jaspers from the Cserhát and the Mátra Mountains. A small group of artefacts was made from raw materials originating from the territories further east, namely: limnoquartzites from the foothills of the Bükk Mountains, and Carpathian obsidians 1 and 2 . On the other hand, raw materials from Transdanubia such as Szentgál type radiolarites or Tevel flint that dominate across the entire western zone of the LBK are absent. Also absent are Western Slovakian raw materials predomi- nant at sites such as e.g. Šturovo ${ }^{20}$ or extralocal Transcarpathian raw materials that occur commonly in Moravia and southeast Slovakia. ${ }^{21}$

The absence of raw materials from the territories to the west and east of Apc is a substantial evidence of the isolation of the LBK groups that inhabited Apc. This isolation is not manifested in ceramic styles which are mainly decorational motifs found in western Slovakia and in the vicinity of Budapest.

The occurrence of a small quantity of obsidian artefacts should not be interpreted in terms of trips-in-search of deposits of this raw material, but - rather - as the evidence of contacts with the Eastern Linear Pottery Culture, just as a few sherds with Tiszadob and Bükk decoration, in the early and in the Želiezovce phases at Apc respectively.

The use of rather poor quality local raw materials influenced the technique of working raw materials which was, first of all, flake or flakeblade technique employed in the whole period of the functioning of Apc. At the same time, already in the oldest phase a limited supply of blade blanks and blade tools, produced elsewhere, is registered.

Although changes in the ceramic style took place, no conspicuous evolution of the lithic industry is recorded. On the other hand, it should be stressed that the oldest phase at Apc exhibits a somewhat separate character. It is unlike the pre-Notenkopf assemblage from the site of Budapest-Aranyhegy. ${ }^{22}$ The small series of lithics from Apc causes that we cannot determine whether the separate nature of the oldest phase at Apc resulted from specific occupations of the inhabitants, or whether it reflects the different techno-morphological tradition. The distinctive feature of the oldest phase at Apc is the absence of blade tools and, in later phases, the almost complete absence of truncations used as sickle inserts. At Apc the function of sickle inserts belonged to unworked bladelets or blade-flakes.

The small degree of diachronic variability of the lithic assemblages could result from the relatively short duration of the functioning of the Apc settlement. The AMS dates are in the interval between $6395 \pm 35$ years BP (Poz-58124) from feature 916 and $6390 \pm 40$ years BP (Poz-51782) from feature 997 for the pre-Notenkopf phase, and $6200 \pm 35$ years BP (Poz-58123) for the Želiezovce phase. The comparison with other

\footnotetext{
17 VirÁg 2009.

18 Marton-Oross 2009.

19 Marton-OrOss 2009.
}

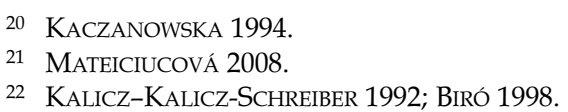


LBK microregions, where the oldest sites in a given agglomeration exhibit a high frequency of extralocal raw materials, allows us to assume that in the region of Apc even older sites of LBK settlers should exist, the settlers who could have brought extralocal raw materials from initial territories of their migration.
It should be emphasized, nevertheless, that both in southwestern Slovakia and in the area around Budapest, the LBK sites are fairly poor in chipped stone artefacts, but among them extralocal raw materials do occur (near Budapest obsidian and Jurassic flint, in western Slovakia first of all Jurassic flint from the region of Cracow).

\section{LITERATURE}

BiRÓ, KATALIN T.

1998 Lithic Implements and the Circulation of Raw Materials in the Great Hungarian Plain during the Late Neolithic Period. Budapest.

2002 Advances in the Study of Early Neolithic Lithic Materials in Hungary. Antaeus (Budapest) 25, $237-241$.

FÖLDVARY, GABOR ZOLTAN

1988 Geology of the Carpathian Region. Singapore-Teaneck.

GERCSÁK, GÁBOR

2002 Hungarian Geographical Names in English Language Publications. Térképtudományi Tanulmányok (Studia Cartologica) (Budapest) 2002, 1-10. [available at: http://lazarus.elte.hu/ guszlev/tajnev/pdf/ gg_studia.pdf. Accessed: 27.12.2013]

HÓK, JOZEF-KAHAN, ŠTEFAN-AUBRECHT, ROMAN

2001 Geológia Slovenska. Bratislava.

KaCZANOWSKA, MAŁGORZATA

1985 Rohstoffe, Technik und Typologie der neolithischen Feuersteinindustrien im Nordteil des Flussgebietes der Mitteldonau. Warszawa.

1994 Erwägungen über die Spaltindustrie aus Štúrovo. In: Pavúk, J. (ed.): Štúrovo - Ein Siedlungsplatz der Kultur mit Linearkeramik und der Želiezovce-Gruppe. Nitra, 115-121.

2003 Distribution of Raw Materials Used in the Chipped Stone Industry of the Western Linear Band Pottery Culture and the Eastern Linear Pottery Culture in the Circum-Carpathian Area. In: Burnez-Lanotte, L. (ed.): Production and Management of Lithic Materials in the European Linearbandkeramik. BAR International Series 1200, Oxford, 5-10.

KacZANOWSKA, MaŁgORZATA-KoZŁOWSKI, JANUSZ K.

2003 Origins of the Linear Pottery Complex and the Neolithic Transition in Central Europe. In: Ammerman, A. J.-Biagi, P. (eds): The Widening Harvest: The Neolithic Transition in Europe: Looking Back, Looking Forward. Boston, 227-248.

KALICZ, NÁNDOR-KALICZ-SCHREIBER, RÓZSA

1992 Die erste frühneolithische Fundstelle in Budapest. Balcanica (Beograd) 23, 47-76.

LESS, GYÖRGY

2011 Geology of Hungary. Miskolc.

MARTON, TiBOR-OROSS, KRISZTIÁN

2009 Reconstructing Space in a Familiar World: The Formation of Late LBK Settlements in Central Transdanubia. In: Kozłowski, J. K. (ed.): Interactions between Different Models of Neolithization North of the Central European Agro-ecological Barrier. Krakow, 51-74.

MATEICIUCOVÁ, INNA

2008 Talking Stones: The Chipped Stone Industry in Lower Austria and Moravia and the Beginnings of the Neolithic in Central Europe (LBK) 5700-4900 BC. Brno.

NÉMETH, NORBERT-PETHŐ, GÁBOR

2009 Geological Mapping by Geobotanical and Geophysical Means: A Case Study from the Bükk Mountains (NE Hungary). Central European Journal of Geosciences (Budapest) 1:1, 84-94.

PELIKÁn PÁl (ed.)

2005 A Bükk hegység földtana. Geology of the Bükk Mountains. Budapest.

PAVÚK, JURAJ

1972 Neolithisches Gräberfeld in Nitra. Slovenská archeológia (Nitra) 20:1, 5-105.

Plašienka, Dusan-Grecula, Pavol-Putiš, Marián-Kováč, Michal-Hovorka, Dušan

1997 Evolution and Structure of the Western Carpathians: An Overview. In: Grecula, P.-Hovorka, D.-Putiš, M. (eds): Geological Evolution of the Western Carpathians. Mineralia Slovaca - Monograph, Bratislava, $1-24$. 
STARNINI, ELISABETTA-SZAKMÁNY, GYÖRGY

1994 Typological and Technological Analysis of the Körös Culture Chipped, Polished and Ground Stone Assemblages of Méhtelek-Nádas (NE Hungary). Atti della Societa per la Preistoria e Protoistoria della Regione Friuli-Venezia Giulia 8, 26-96.

1998 The Lithic Industry of the Neolithic Sites of Szarvas and Endrőd (South-Eastern Hungary): Technotypological and Archaeometrical Aspects. Acta Archaeologica Academiae Scientiarum Hungaricae (Budapest) 50, 279-342.

SZAKMÁNY, GYÖRGY

1996 Results of the Petrographical Analysis of some Samples of the Ground and Polished Stone Assemblage. In: Makkay, J.-Starnini, E.-Tulok, M. (eds): Excavations at Bicske-Galagonyás (part III). The Notenkopf and Sopot-Bicske Cultural Phases. Trieste, 224-241.

SZAKMÁNY, GYÖRGY-STARNINI, ELISABETTA

2002 Petrographical Analysis of Polished Stone Tools from some Neolithic Sites of Hungary. In: Jerem, E.Biró, K. T. (eds): Proceedings of 31th International Symposium of Archaeometry. BAR International Series 1043, Oxford, 811-818.

VARGa GyUla-Csilllagné TePláNSZKY ERIKA-FÉLEgYHÁZI ZsOlt

1975 A Mátra hegység földtana. Geology of the Mátra Mountains. A Magyar Állami Földtani Intézet Évkönyve 57. Budapest.

VIRÁG, ZsUZSA M.

2009 The Eastern Periphery of the Central European LPC in the Region of Budapest (Connections between the Transdanubian LPC and the Alfold LPC). In: Kozłowski, J. K. (ed): Interactions between Different Models of Neolithization North of the Central European Agro-ecological Barrier. Krakow, 9-30.

VOZÁr, JOZEF-VOJTKO, RASISLAV-SLIVA, L'UBOMIR

2002 Guide to the Geological Excursions. 17th Congress of Carpathian-Balkan Geological Association, Bratislava.

\title{
A VONALDÍSZES KERÁMIA KULTÚRÁJÁNAK (VK) KÖIPARA APCRÓL
}

\author{
MaŁgorzata KacZanOWSKA - JanUSZ K. KoZŁOWSKI - MichaŁ WASILEWSKI
}

Az apci lelőhely a vonaldíszes kerámia kultúrája (VK) elterjedési területének keleti perifériáján helyezkedik el. Az ásatásokon beigazolódott, hogy a település több fázison keresztül - a kottafejes időszak előttől a zselízi időszakig - fennállt. Így a VK pattintottkő-iparának helyi fejlődése a lelőhelyen tanulmányozható.

Apcon a VK-objektumok 408 pattintott kőleletet tartalmaztak. A fő technológiai kategóriák összetételét az 1. táblázat mutatja be. Más északnyugat-magyarországi és délnyugat-szlovákiai VK-lelőhelyekkel összevetve a kőegyüttes itt széles spektrumot mutat. A feltárt terület nagyságát és a VK mindegyik fázisának jelenlétét figyelembe véve a fázisokra és települési egységekre eső kőleletek száma alacsony.

A leletanyag általános összetétele arra utal, hogy a lelőhelyen egyedi, kis mennyiségú helyi kőeszközkészítés folyt. A pengék szerepe csekély, a szilánkok jelentősebbek voltak. Az eszközök többsége szilánkon készült. A magkövek aránya meglehetósen magas, amit feltehetóleg a nyersanyagok gyenge minősége és rossz hasadása okozott.

A felhasznált nyersanyagok többsége kovás kőzet, föleg limnokvarcitok (közel 70\%). A leggyakoribb limnokvarcittípusok a lelőhelytől 20 km-nyi távolságból, a Mátra déli és délnyugati részéról és a Cserhátból származtak. Egyes limnokvarcitok forrása lehet Gyöngyöstől nyugatra, valamint a miskolci Avas (a lelóhelytől mintegy 70-80 km-re keletre). Az egyetlen távolsági nyersanyag az obszidián volt, de aránya csupán 1,7\%. Ezenfelül a 762. gödörben $20-40 \mathrm{~cm}$ mélyen elókerült egy vakaró, melynek anyaga a Felső-Dnyeszter-medencéből származó kréta kori tűzkő, amely azonban valószínúleg fiatalabb korhoz tartozó, bekeveredett darab. Ha összehasonlítjuk az apci ipart olyan VK-lelőhelyek kőegyütteseivel, amelyek a kultúra keleti peremének közelében helyezkednek el, akkor a következó különbségeket fedezhetjük fel:

Apcon a helyi és a regionális nyersanyagforrások voltak a legjelentősebbek. A regionális források főként a lelőhelytől keletre találhatók. Ezzel szemben a VK más, keleti peremterületi lelőhelyein, Budapest környékén (Budapest-Aranyhegy) és az Ipoly-völgyben (SzécsényÜltetés) a dunántúli nyersanyagokhoz (Szentgál típusú radiolarit, teveli kova) gyakran társulnak „északi” túzkövek (főként jura koriak Krakkó környékéről). SzécsényÜltetésen különösen magas az obszidián aránya.

A távolsági nyersanyagok (obszidián, bükki limnokvarcitok) ritkán és valószínúleg szupport vagy kész eszköz formájában érkeztek a telepre. Csupán egyetlen olyan kőeszköz került elő a zselízi fázisba sorolt objektumból, amely Kárpátokon túli nyersanyagból (krakkói jura túzkőből) készült. Közép-Európában a VK formatív vagy korai fázisába tartozó számos lelőhelyén a távolsági nyersanyagok dominálnak, mivel az új telepesek rendszerint a bölcsőterületről hozzák a kőnyersanyagaikat. Lehetséges, hogy Apc nem a legkorábbi lelőhely a térségben, $\mathrm{s}$ további ásatások során idősebb telepekre bukkanhatnak. 
Az inkább gyenge minőségúnek tekinthető helyi nyersanyag felhasználása befolyásolta a megmunkálás módját, amely elsősorban szilánk vagy pengeszerú szilánk elóállítására irányult az apci VK-települések fennállásának teljes időszakában. Ugyanakkor korlátozott számban már a legkorábbi fázisban is megjelennek a telepen máshol előállított pengeszupportok és pengeeszközök.

Bár a kerámiastílusban változások következtek be, a kőiparban nem látható egyértelmú átalakulás. Másrészt ki kell emelni, hogy Apcon a legidősebb fázis némileg különálló jelleget mutat. Mivel azonban csak kisszámú együttesról van szó, nem határozható meg, hogy a legkorábbi fázis különálló jellege egy speciális megtelepedési mód eredménye, vagy egy eltérő technomorfológiai hagyományt tükröz. Az apci település többitől eltérő jelensége a legkorábbi fázisban a pengeeszközök, a későbbi fázisokban pedig a sarlóbetétként használt csonkított pengéknek a szinte teljes hiánya. A sarlóbetétek szerepét Apcon megmunkálatlan lamellák vagy pengeszerú szilánkok töltötték be. A szupportok általános elóállítási módja és a nyersanyag-összetétel nem változik jelentősen a kottafejest megelőző fázistól a zselízi fázisig.

Apcon 224 szerszámkőlelet került elő: alsó és felső őrlőkövek (féltermék is), csiszolt felületú kőlapok, ütőkövek, őrlókövek/mozsártörők, valamint ezek töredékei. A szerszámkövekhez felhasznált nyersanyagok vagy helyiek (kvarc, konglomerátum, homokkő), melyeket részben folyóvízi üledékből szedtek, vagy a magyar-szlovák határon levő hegyekből származnak, mint a gabbró és a bazalt (többek között a Bükk hegység pereméról), azaz mintegy $50 \mathrm{~km}$ távolságról. Kis mennyiségben fordulnak elő andezitek, valószínúleg a Mátrából. A szerszámkövek készítéséhez felhasznált nyersanyagok uralkodóan regionális forrásokból, míg a pattintottkő-ipar nyersanyagai döntően helyi forrásokból erednek. A szembeszökő következetlenségnek (vagyis, hogy a nehéz szerszámkövek anyagát nagyobb távolságról hozták, mint a könnyú pattintottkó-eszközökét) az lehet a magyarázata, hogy a szerszámkövek esetében nehézségekbe ütközött a regionális nyersanyagok kiváltása helyi kőzetekkel. Csupán egyetlen miniatứr csiszolt kőbalta került elő feketészöld palából. Érdemes megjegyezni, hogy Apcon nincsenek kaptafa alakú balták, miközben ez a típus gyakori Délnyugat-Szlovákiában, különösen sírokban (NitraPremyslova ulica - PAVÚK 1972).

Az Apctól nyugatra fekvő területekről származó nyersanyagok hiánya fontos bizonyítéka az apci VKcsoportok izolációjának. Ám ez az elkülönülés nem mutatkozik meg a kerámiák stílusában, amelyek díszítómotívumai megegyeznek a Nyugat-Szlovákiában és a Budapest környékén találtakkal. Az északkelet-magyarországi AVK-területekkel valamilyen mértékben meglévő kapcsolatokat nemcsak az onnan behozott regionális nyersanyagok igazolják, hanem tiszadobi és bükki importkerámiák is. 